\title{
A key to the past? Element ratios as environmental proxies in two Arctic bivalves
}

\author{
Mikko Vihtakari ${ }^{\mathrm{a}, \mathrm{b}, \mathrm{c}, *}$, William G. Ambrose Jr. ${ }^{\mathrm{c}, \mathrm{d}, \mathrm{e}}$, Paul E. Renaud ${ }^{\mathrm{c}, \mathrm{f}}$, \\ William L. Locke V ${ }^{\mathrm{d}}$, Michael L. Carroll ${ }^{\mathrm{c}, \mathrm{g}}$, Jørgen Berge ${ }^{\mathrm{a}, \mathrm{f}}$, Leon J. Clarke ${ }^{\mathrm{h}}$, \\ Finlo Cottier ${ }^{\mathrm{i}, \mathrm{a}}$, Haakon Hop ${ }^{\mathrm{a}, \mathrm{b}}$ \\ ${ }^{a}$ Department of Arctic and Marine Biology, UiT The Arctic University of Norway, N-9037 \\ Tromsø, Norway \\ ${ }^{b}$ Norwegian Polar Institute, Fram Centre, N-9296 Tromsø, Norway \\ ${ }^{c}$ Akvaplan-niva, Fram Centre, N-9296 Tromsø, Norway \\ ${ }^{d}$ Department of Biology, Bates College, Lewiston, Maine 04240, USA \\ ${ }^{e}$ Division of Polar Programs, National Science Foundation, Arlington, Virginia 22230, USA \\ ${ }^{f}$ University Centre in Svalbard, N-9171 Longyearbyen, Norway \\ ${ }^{g}$ Centre for Arctic Gas Hydrate, Environment and Climate, Department of Geology, UiT \\ The Arctic University of Norway, N-9037 Tromsø, Norway \\ ${ }^{h}$ School of Science and the Environment, Faculty of Science and Engineering, Manchester \\ Metropolitan University, Manchester M1 5GD, UK \\ ${ }^{i}$ Scottish Association for Marine Science, Scottish Marine Institute, Oban, Argyll PA37 \\ $1 Q A, U K$
}

\begin{abstract}
Understanding rapid climate change in the Arctic and its ecosystem implications requires more information on the environment at temporal resolutions and time-periods not available from instrumental records. Such information can be acquired through geochemical proxy records, but sub-annual records are rare. We analyzed shell material of bivalve mollusks (Serripes groenlandicus and Ciliatocardium ciliatum) placed on oceanographic moorings for one year in two Arctic fjords to assess the potential use of shell elemental ratios as environmental proxies. $\mathrm{Li} / \mathrm{Ca}, \mathrm{Mg} / \mathrm{Ca}, \mathrm{Li} / \mathrm{Mg}, \mathrm{Li} / \mathrm{Sr}, \mathrm{Mn} / \mathrm{Ca}, \mathrm{Sr} / \mathrm{Ca}, \mathrm{Mo} / \mathrm{Ca}$, and $\mathrm{Ba} / \mathrm{Ca}$ were determined using Laser-Ablation Inductively-Coupled-Plasma Mass-Spectrometry. Combining data from moorings with previously derived

\footnotetext{
Email addresses: mikko.vihtakari@gmail.com (Mikko Vihtakari), wambrose@bates.edu
}

* Corresponding author (William G. Ambrose Jr.), paul.renaud@akvaplan.niva.no (Paul E. Renaud), wlocke@bates.edu (William L. Locke V), michael.carroll@akvaplan.niva.no (Michael L. Carroll), jorgen.berge@uit.no (Jørgen Berge), 1.clarke@mmu.ac.uk (Leon J. Clarke), finlo.cottier@sams.ac.uk (Finlo Cottier), haakon.hop@npolar.no (Haakon Hop)
\end{abstract}

Preprint submitted to Palaeogeography, Palaeoclimatology, Palaeoecology September 27, 2016 
sub-annual shell growth models allowed us to relate the elemental ratio patterns to oceanographic parameters (temperature, salinity, and fluorescence). Shell $\mathrm{Ba} / \mathrm{Ca}$ profiles were characterized by abrupt peaks occurring 11 to 81 days after the phytoplankton bloom, as indicated by an index of seawater fluorescence. $\mathrm{Li} / \mathrm{Ca}$ and $\mathrm{Mg} / \mathrm{Ca}$ values exhibited significant logarithmic relationships with shell growth rate, indicated by marginal $\mathrm{R}^{2}$ values of 0.43 and 0.30 , respectively. These ratios were also linearly related to temperature, with marginal $\mathrm{R}^{2}$ values of 0.15 and 0.17 , respectively. $\mathrm{Mn} / \mathrm{Ca}$ and $\mathrm{Sr} / \mathrm{Ca}$ ratios exhibited variability among individuals and their temporal pattern was likely controlled by several unidentified factors. Mo/Ca patterns within the shells did not demonstrate correlations with any of the oceanographic parameters. Our results reflect complex relationships between elemental ratios and bivalve metabolism, methodological limitations, as well as contemporaneous environmental processes, suggesting that none of the studied elemental ratios can be used as unequivocal proxies of seawater temperature, salinity, paleoproductivity, or shell growth rate. Despite this, $\mathrm{Ba} / \mathrm{Ca}$ and $\mathrm{Li} / \mathrm{Ca}$ can be used as sub-annual temporal anchors in further studies because the variability of these elements was synchronized in each fjord. Keywords: Serripes groenlandicus, Ciliatocardium ciliatum, Laser-Ablation Inductively-Coupled-Plasma Mass-Spectrometry, paleoclimatology, paleoceanography, bivalve shells

\section{Introduction}

Bivalve shells offer keys for interpreting past environmental conditions. Food supply, temperature, salinity, and other factors can be reflected in growth rate and mineralogy of shell carbonate, and can show distinct temporal variability.

5 For example, shell growth of bivalve mollusks is often regulated by food and temperature, and visible lines demonstrate seasonal patterns in growth (Chauvaud et al., 1998, Schöne et al., 2005a; Chauvaud, 2005; Ambrose et al., 2006, Carroll et al. 2011a b, 2014, Vihtakari et al. 2016). These growth lines can be used as time markers to develop a chronology of shell deposition (e.g. Jones, 
1980 Schöne et al., 2005b, Wanamaker et al., 2012). Multiple shells can be cross-dated to construct chronologies that can span multiple centuries, with the further possibility of using the geochemical signature of shell material as an indicator of the environment during shell-deposition (Pearson and Palmer, 2000 Strom et al., 2004; Wanamaker et al., 2012, Butler et al., 2013, Masson-Delmotte 15 et al. 2013).

Bivalves are distributed across a wide range of habitats and latitudes (Dame 2012), and their shells are well represented in the geological record (Krantz et al. 1987, Valentine et al., 2006, Clapham and Bottjer, 2007; Dame, 2012). Two common circumpolar filter-feeding bivalve species, the Greenland cockle (Serripes groenlandicus Mohr, 1786) and the hairy cockle (Ciliatocardium ciliatum Fabricius, 1780), have been used as environmental and climatic indicators in previous studies (Ambrose et al. 2006, Sejr et al., 2009, Carroll et al., 2011a b, 2014). They are long-lived species, with maximum longevity of 30-60 years, forming aragonitic shells with prominent annual growth lines. These growth lines are deposited during a slow winter shell-growth period that is regulated by low food availability (Khim et al., 2003, Carroll et al., 2009, Sejr et al., 2009. Selin, 2010, Ambrose et al. 2012, Henkes et al., 2013, Vihtakari et al. 2016). Shell growth of bivalves is further affected by temperature and often correlates with large-scale climatic drivers over annual to decadal scales Ambrose et al.

30 2006, Carroll et al., 2011a b; Ambrose et al., 2014, Carroll et al. 2014).

In theory, the environmental information stored in bivalve shells can be used to reconstruct seawater conditions with a sub-annual resolution based on geochemical proxies, such as element-to-calcium ratios, that are sampled along chronologically deposited shell material (Klein et al., 1996, Richardson, 2001

35 Wanamaker et al. 2011). Elements are incorporated into the shell during growth (Wheeler, 1992, Weiner and Dove, 2003, Marin, 2012). Uptake of these elements can occur directly from ambient water in dissolved form, but also from molecules or from food particles (Zhao et al., 2015). Several elemental ratios, such as Li/Ca (Thébault et al., 2009b, Thébault and Chauvaud, 2013), Mg/Ca (Dodd, 1965

40 Klein et al. 1996, Pearce and Mann, 2006), Sr/Ca (Dodd, 1965, Richardson 
2004), and Sr/Li (Füllenbach et al. 2015) have been suggested as proxies of seawater temperature in bivalve shells. These ratios are, however, often affected by metabolic processes. Further, shell growth rate might be correlated with crystal growth rate (kinetics) of calcium carbonate (Swan, 1953, Purton et al., 1999 ,

45 Takesue and van Geen, 2004, Gillikin et al., 2005, Lorrain et al., 2005), and thus $\mathrm{Li} / \mathrm{Ca}, \mathrm{Mg} / \mathrm{Ca}$ and $\mathrm{Sr} / \mathrm{Ca}$ may be used as temperature proxies in specific cases when shell growth rate and seawater temperature are strongly intercorrelated (Schöne et al., 2011). Lithium-to-magnesium ratios could be used to tease apart the metabolic and growth rate effects associated with $\mathrm{Li} / \mathrm{Ca}$ and $\mathrm{Mg} / \mathrm{Ca}$ in corals (Case et al., 2010, Hathorne et al., 2013; Rollion-Bard and Blamart, 2015). The ratios of barium, manganese, molybdenum, and lithium-to-calcium have been suggested as proxies of pelagic productivity (Vander Putten et al. 2000, Gillikin et al. 2006, Barats et al., 2010, Thébault and Chauvaud, 2013). Barium-to-calcium provides the most consistent elemental ratio signal in bivalve shells: $\mathrm{Ba} / \mathrm{Ca}$ profiles are characterized by a flat background signal that is periodically interrupted by sharp peaks in a wide range of species across various habitats and latitudes (Stecher et al., 1996; Toland et al., 2000; Vander Putten et al., 2000, Torres et al., 2001; Lazareth et al., 2003, Gillikin et al., 2006, 2008, Barats et al., 2009, Carroll et al., 2009, Elliot et al., 2009, Thébault et al., 2009a,

60 Marali et al., 2015). Barium-to-calcium ratios have been shown to reflect Ba concentration in ambient seawater (Gillikin et al. 2006; Tabouret et al., 2012, Poulain et al. 2015) that might in some cases be associated with primary productivity. In contrast, manganese is often associated with shell precipitation rate and may also be influenced by seawater redox conditions, and therefore shows variable species specific patterns (Carré et al., 2006, Freitas et al., 2006, 2009, Shirai et al., 2008, Ullmann et al., 2013). Finally, molybdenum may be incorporated through diet, making $\mathrm{Mo} / \mathrm{Ca}$ a potential proxy of paleoproductivity (Barats et al., 2010, Tabouret et al., 2012).

The exploration of elemental ratios in bivalve shells as environmental proxies 70 is valuable, especially in the Arctic where instrumental records are short or interrupted and climate change is rapid (Wassmann et al., 2011). Interpretation 
of these geochemical proxies is complicated by shell growth rate, which varies through the year (Vihtakari et al. 2016) and appears to influence some element ratios (Fig. 4 in Vihtakari, 2014). Consequently, understanding sub-annual shell-growth patterns is a fundamental prerequisite for using any shell-based proxy at sub-annual resolution. Very few studies, and none in the Arctic, have been able to relate sub-annual patterns of elemental ratios within bivalve shells to seawater parameters recorded at the growth location.

In this study, we examine elemental ratios within the shells of $S$. groenlandicus and $C$. ciliatum, and assess their potential use as environmental proxies. We deployed these bivalves on moorings in two oceanographically contrasting fjords in Svalbard for one year (Ambrose et al., 2012, Vihtakari et al., 2016). The bivalve deployment, combined with previously obtained sub-annual growth models (Vihtakari et al., 2016), allowed us to relate the elemental ratio patterns to the oceanographic data recorded by mooring instrumentation. We aimed to determine whether: 1) $\mathrm{Li} / \mathrm{Ca}, \mathrm{Ba} / \mathrm{Ca}, \mathrm{Mn} / \mathrm{Ca}$ or $\mathrm{Mo} / \mathrm{Ca}$ could be used as proxies of primary productivity, as has been suggested by other studies, 2) Li/Ca, $\mathrm{Li} / \mathrm{Mg}, \mathrm{Li} / \mathrm{Sr}, \mathrm{Mg} / \mathrm{Ca}$ or $\mathrm{Sr} / \mathrm{Ca}$ could be used as proxies of temperature or shell growth rate, and 3) any of the above-mentioned elemental ratios were deposited simultaneously in different individuals, thereby indicating that they can be used as sub-annual chronological markers in the studied species.

\section{Materials and Methods}

\subsection{Study design}

A suite of element-( $\mathrm{Li}, \mathrm{Mg}, \mathrm{Mn}, \mathrm{Sr}, \mathrm{Mo}$, and $\mathrm{Ba})$-to-calcium ratios was examined at sub-annual resolution in shells of two bivalve species ( $S$. groenlandicus and $C$. ciliatum). The specimens were deployed on oceanographic moorings for one year during September 2007-2008 and September 2009-2010 in two

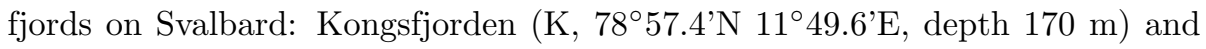
Rijpfjorden (R, $80^{\circ} 18^{\prime} \mathrm{N} 22^{\circ} 20^{\prime} \mathrm{E}$, depth $220 \mathrm{~m}$ ). These two fjords are oceanographically different. Kongsfjorden is an Atlantic water-influenced open fjord, 
whereas Rijpfjorden is a fjord with a sill (depth 100-200 m) that is influenced mainly by Arctic water masses (Svendsen et al., 2002, Howe et al., 2010, Wallace et al. 2010, Søreide et al. 2010). Kongsfjorden was ice-free throughout the field deployment with the exception of occasional drift ice, whereas Rijpfjorden was ice-covered for 8 months (January 21-September 16) in 2007-2008 (Norwegian Meteorological Institute, 2014), and for 5 months (February 15-July 21) in 2009-2010 (Vihtakari et al., 2016). The bivalve deployment on moorings is described in detail by Ambrose et al. (2012) and Vihtakari et al. (2016). In brief, bivalves were collected east of Spitsbergen $\left(76^{\circ} 30^{\prime} \mathrm{N} 25^{\circ} 56^{\prime} \mathrm{E}\right.$, depth $\left.75 \mathrm{~m}\right)$ in August 2007 and from Spitsbergenbanken ( $76^{\circ} 1^{\prime} \mathrm{N} 19^{\circ} 56^{\prime} \mathrm{E}$, depth $\left.120 \mathrm{~m}\right)$ in August 2009. They were held in flow-through seawater tanks for 1-4 weeks at the University Centre in Svalbard and incubated in seawater with $125 \mathrm{mg} \mathrm{L}^{-1}$ of calcein dye for $24 \mathrm{~h}$ immediately before they were placed in $7 \mathrm{~mm}$ mesh plastic cages (hereafter baskets) on the oceanographic moorings. Each basket contained 15-18 bivalves, providing free water-flow for all specimens. The baskets did not contain sediments. The calcein mark was used as an absolute time marker of deployment and was identified in sectioned shells using fluorescent imaging (see Vihtakari et al., 2016). During 2009-2010, the bivalves were deployed at two water depths, $15 \mathrm{~m}$ (basket A) and $25 \mathrm{~m}$ (basket B), while in 2007-2008 they were deployed only at $25 \mathrm{~m}$ (Table 1 ).

Bivalves collected from the moorings were sacrificed and shells then were embedded in two-component epoxy (as described in Ambrose et al., 2012). Embedded shells were cut into thick-sections along the maximum growth axis, as described in Vihtakari et al. (2016), and the thick-sections were ground and polished to a thickness of $2.0 \pm 0.1 \mathrm{~mm}$. These thick-sections then were transferred to a clean room, where they were rinsed and brushed in Milli-Q water, sonicated for $5 \mathrm{~min}$ and rinsed again. Finally, the thick-sections were left to dry overnight in room temperature before they were analyzed using LaserAblation Inductively-Coupled-Plasma Mass-Spectrometry (hereafter LA-ICPMS). Eleven shells were further analyzed for in situ $\delta^{18} \mathrm{O}$ values using secondary ion mass spectrometry (SIMS) to determine sub-annual growth models 
(see Vihtakari et al. 2016, for data and analytical methods). Measured element ratio patterns determined for nine shells that exhibited shell growth adequately reproduced by growth models were compared to weekly averages of seawater temperature, salinity and fluorescence index records obtained from mooring instruments located adjacent to bivalve baskets (Table2, Section 2.3, see Vihtakari et al. 2016 for details about mooring instrumentation).

\subsection{Elemental ratio analyses}

LA-ICP-MS (Mokgalaka and Gardea-Torresdey, 2006) was conducted at the Plasma Mass Spectrometry Facility, Woods Hole Oceanographic Institute (MA, US), using a Thermo-Finnigan Element 2 sector field ICP-MS coupled to a New Wave Laser UP $193 \mathrm{~nm}$ excimer laser ablation system. A sequence of sample spots was ablated along the middle of the shell thick-section from the outer margin to the calcein line (see Figure 1 and Vihtakari et al. 2016) using 95 s dwell time, $10 \mathrm{~Hz}$ repetition rate and $90 \%$ output power. Analyses were conducted in 2009 and 2011 for specimens recovered in 2008 and 2010, respectively. Magnesium $\left({ }^{25} \mathrm{Mg}\right)$, calcium $\left({ }^{48} \mathrm{Ca}\right)$, manganese $\left({ }^{55} \mathrm{Mn}\right)$, strontium $\left({ }^{88} \mathrm{Sr}\right)$ and barium $\left({ }^{138} \mathrm{Ba}\right)$ were analyzed in both years. Molybdenum $\left({ }^{98} \mathrm{Mo}\right)$ and lithium $\left({ }^{7} \mathrm{Li}\right)$ were added to the analysis for 2009-2010 samples. Due to the low concentration of Mo in the $\mathrm{CaCO}_{3}$ matrix, 2009-2010 shells had a larger ablation crater size $[\bar{x}=87.5 \pm 0.7 \mu \mathrm{m}$ (standard error of the mean, SE), $\mathrm{n}=612]$ compared to 2007-2008 samples $[\bar{x}=42.0 \pm 0.3 \mu \mathrm{m}(\mathrm{SE}), \mathrm{n}=311]$. The distance between laser spots $[\bar{x}=104.1 \pm 14.3$ (standard deviation, SD) $\mu \mathrm{m}$ ] was kept constant between sessions and samples, and therefore the number of ablation spots varied between 17 and 64 per analyzed shell depending on the length of annual growth increment.

The signal intensity (counts per second) of the analyzed elements was monitored in an Element2 low resolution mode during the LA-ICP-MS analyses. The recording of element signal intensity was started approximately $10 \mathrm{~s}$ after initiating the laser ablation to clean the shell surface of debris and to ensure that the ablation fume had reached the ICP-MS. An estimated value for each 
element was generated by averaging 50 signal intensity measurements during the peak of material flow. Nitric acid $\left(5 \mathrm{vol} \% \mathrm{HNO}_{3}\right)$ was used as a blank, ensuring a constant flow of the acid into the ICP-MS. Every tenth sample analyzed was a blank. The moving average of blanks was calculated and subtracted from the data. Since the analyzed shell matrix was predominantly aragonite (Khim et al. 2003. Henkes et al. 2013), ${ }^{48} \mathrm{Ca}$ was used as an internal standard by normalizing all other elements to Ca concentration (Vander Putten et al., 1999). Two liquid standards, Japanese Certified Reference Material or "JpnCRM" (Yoshinaga et al. 2000) and FEBS-1 (Sturgeon et al., 2005), were run as every tenth and twentieth sample, respectively. These standards were used to correct for instrument drift and to calibrate elemental ratios to cover all isotopes. FEBS-1 was used for $\mathrm{Mn} / \mathrm{Ca}$ and $\mathrm{Li} / \mathrm{Ca}$ and JpnCRM for the other elemental ratios. The reference materials did not have a certified value for Mo. Therefore, Mo/Ca concentrations are given as percentage of Mo/Ca maximum for each shell and comparison of absolute $\mathrm{Mo} / \mathrm{Ca}$ values was not possible. $\mathrm{Li} / \mathrm{Mg}$ and $\mathrm{Li} / \mathrm{Sr}$ ratios were calculated from the corresponding ratios to calcium using ${ }^{48} \mathrm{Ca}$ as an internal reference.

\subsection{Datasets and statistical analyses}

LA-ICP-MS sampling was targeted in the middle of a bivalve shell section, resulting in samples being taken mostly from the composite fibrous prismatic outer shell layer (Figure 1, Schneider and Carter, 2001). The position of the sample spots was related to sub-annual growth lines and a distance axis that [was related to the historical location of the shell margin using ImageJ (Schnei-

der et al., 2012) and sclero package (Vihtakari, 2016) for R software (R Core Team, 2016), as described in Vihtakari et al. (2016). The method also allowed a spatial estimation of averaging error (Goodwin et al., 2004, Beelaerts et al., 2008). Resulting LA-ICP-MS sample distances are therefore expressed as mm from deployment (i.e. the calcein mark) along the distance axis, together with minimum and maximum extents for each LA-ICP-MS sample spot (Figures B.9. B.14). 
Growth models for nine shells (three from each basket: KB, RA and RB, Table 1), based on estimated daily growth trajectories for SIMS $\delta^{18} \mathrm{O}$ centroids (Figure 9 in Vihtakari et al., 2016), allowed comparison of elemental ratio data

measure of relative effect for each fixed effect. Linear mixed-effect models were calculated using the nlme package (Pinheiro and Bates, 2014). The variabil- 
ity in relationships between response and predictor variables among individual samples was examined using linear regression models fitted for each sample, response variable and predictor variable separately (Model 3; Appendix A).

Coefficients of variation (CV) for minimum and maximum elemental ratios over the mooring deployment were used to assess among-individual consistency of elemental ratios using all analyzed shells over two deployment periods $(\mathrm{n}=$ 30, Table 1). Correlations between elemental ratios and predictor variables for regression models were examined using principal component analysis (Pearson, 1901) calculated on correlation matrices averaged over samples using Fisher ztransformation $\left(r_{z}\right)$ (Fisher, 1921, Corey et al., 1998; Bonett and Wright, 2000). These correlation matrices are presented in Table B.9.

The relative importance of the predictor variables (Genizi, 1993), (1) cultivation basket, (2) bivalve age and (3) growth increment length during mooring deployment to the total variance explained by these three factors was analyzed using the Lindemann-Merenda-Gold method (Lindeman et al., 1980) on linear models of minimum and maximum element ratios. The analyses were conducted using the relaimpo package (Grömping, 2006) for R.

\section{Results}

\subsection{Oceanographic conditions in the fjords}

Kongsfjorden experienced warmer temperatures in 2007-2008 than in 20092010 (Figure 2): The autumn (September to December) temperatures in Kongsfjorden were on average $1.0{ }^{\circ} \mathrm{C}$ higher in 2007 compared to 2009 , the winter (January to April) temperatures $1.7^{\circ} \mathrm{C}$ warmer, and the spring/summer (May to September) temperatures $2.6{ }^{\circ} \mathrm{C}$ warmer in 2008 compared to 2010 . In contrast, temperature differences between years varied seasonally in Rijpfjorden: The autumn (September to November) temperatures in Rijpfjorden were also on average $1.0{ }^{\circ} \mathrm{C}$ higher in 2007 compared to 2009 , the winter (December to May) temperatures were almost equal between years, but the summer temperatures were on average $2.4{ }^{\circ} \mathrm{C}$ higher in 2010 compared to 2008. In Kongsfjorden, 
temperature began to increase in May in both years. In 2007-2008, temperature remained above zero, while in the winter of 2009-2010, temperature was generally below zero. Temperature was recorded at two depths (15 and $25 \mathrm{~m}$ ) in 2009-2010. Temperature differences between depths were generally small, except during the summer stratification period, when temperature at $15 \mathrm{~m}$ was approximately $1{ }^{\circ} \mathrm{C}$ higher than at $25 \mathrm{~m}$. Rijpfjorden experienced temperatures close to $-1.7^{\circ} \mathrm{C}$ from January until July (6 months) in 2007-2008 and from January until June (5 months) in 2009-2010. Temperature rose abruptly in mid-July 2010, whereas in 2008 it started to increase in mid-May, but did not exceed $0{ }^{\circ} \mathrm{C}$. In 2009-2010, temperatures were similar at both measured depths until late August, when the surface layer cooled by approximately $3^{\circ} \mathrm{C}$ relative to the deeper $(25 \mathrm{~m})$ layer.

In both fjords, the fluorescence index (FLI) was close to zero prior to a dramatic increase during the spring (Figure 2). The first fluorescence peak occurred later (mid-June to mid-July) in Rijpfjorden than in Kongsfjorden (midMay to beginning of June). Salinity was relatively stable in Kongsfjorden, with a range between 33.3 and 35.0 (Figure 2). Rijpfjorden experienced a variable salinity regime, related to melt water from sea ice, from July to December. Salinity varied more in 2009-2010 (30.6-34.6) than in 2007-2008 (31.7-34.3), and was most variable at the shallow baskets $(15 \mathrm{~m})$.

\subsection{Patterns in element ratio profiles}

\subsection{1. $\mathrm{Li} / \mathrm{Ca}$}

Lithium-to-calcium ratios were consistently lower during winter and increased after the winter growth band in all studied shells (Figures 3, B.11 B.14]. The increase occurred simultaneously with increased growth rate in the growth modeled shells (Figures 3. B.15). On average, minimum Li/Ca was $13.9 \pm 0.3(\mathrm{SE}, \mathrm{n}$ $=22) \mathrm{mmol} \mathrm{mol}^{-1}$ (Table 3 . The Li/Ca minimum occurred sometime between October and late May in Kongsfjorden and between October and mid-July in Rijpfjorden (Figure 3). Coefficient of variation for minimum Li/Ca values varied between 7.5 and $14.1 \%$ among baskets and was higher than that for maximum 
values (Table 3). The maximum values were, on average, $21.6 \pm 0.3 \mu \mathrm{mol} \mathrm{mol}^{-1}$ $(\mathrm{SE}, \mathrm{n}=22)$ and were estimated to occur from July to early September in Kongsfjorden and mid-July to early August in Rijpfjorden (Figure 3).

\subsection{2. $\mathrm{Mg} / \mathrm{Ca}$}

Magnesium-to-calcium ratios were at their lowest in the winter growth band and increased immediately thereafter toward the end of the winter growth period in most analyzed shells (Figures 3 B.9 B.14). Three shells deployed in Rijpfjorden in 2007, however, did not demonstrate clear seasonal Mg/Ca fluctuations (Figure B.10). The strongest increase in $\mathrm{Mg} / \mathrm{Ca}$ values occurred during spring, coinciding with increased growth rate (Figures 3, B.16). After reaching the maximum in July to mid-August in Kongsfjorden and in late July to late August in Rijpfjorden, $\mathrm{Mg} / \mathrm{Ca}$ values decreased slightly until the end of the deployment period (Figure 3). Maximum $\mathrm{Mg} / \mathrm{Ca}$ values ranged between 1.04 and $4.15 \mathrm{mmol} \mathrm{mol}^{-1}$ being generally higher in 2009-2010 than in 2007-2008 (Table 3). Minimum $\mathrm{Mg} / \mathrm{Ca}$ values ranged between 0.39 and $1.70 \mathrm{mmol} \mathrm{mol}^{-1}$ and were not obviously different among years. Coefficient of variation for $\mathrm{Mg} / \mathrm{Ca}$ minimum and maximum values was higher than that for Li/Ca (Table 3).

\subsection{3. $\mathrm{Mn} / \mathrm{Ca}$}

Manganese-to-calcium values exhibited variable patterns, but were also characterized by peaks in the translucent summer growth band in 24 of 30 analyzed shells (Figure B.9 B.14). These peaks were in recorded in shell portions laid down between late May and August in Kongsfjorden, and between early July and early August in Rijpfjorden, occurring one to 70 days after the fluorescence peak (Table 4 and Figure 3). Low Mn/Ca values were measured in the winter growth band (Figure B.17). Average maximum manganese values ranged between 1.31 and $8.52 \mathrm{\mu mol} \mathrm{mol}^{-1}$ (Table 3). Maximum Mn/Ca values within baskets showed substantial variability as illustrated by a high coefficient of variation (Table 3). Average minimum Mn/Ca values ranged between 0.16 and 0.75 umol mol ${ }^{-1}$ among baskets, with high coefficient of variation (Table 3). Aver- 
age minimum and maximum values were lower in 2009-2010 than in 2007-2008

(Table 3).

\subsection{4. $\mathrm{Sr} / \mathrm{Ca}$}

Individuals within baskets demonstrated considerable variability with respect to $\mathrm{Sr} / \mathrm{Ca}$ profiles (Figures 3, B.9 B.14). Minimum values were recorded before the winter growth band in three samples, during the winter growth in four samples, and after the winter growth in 23 samples. Furthermore, maximum $\mathrm{Sr} / \mathrm{Ca}$ values occurred before, during and after the winter growth band in 7, 7, and 16 samples, respectively (Figures B.9 B.14). Minimum $\mathrm{Sr} / \mathrm{Ca}$ values occurred in shell portions formed between May and August in two growth modeled S. groenlandicus from Kongsfjorden and between October and March in the growth modeled C. ciliatum specimen (Figures 3 and B.18). In Rijpfjorden, the minimum values were recorded between July and mid-August in five shells and between April and mid-July in one S. groenlandicus specimen (Figure 3). Maximum $\mathrm{Sr} / \mathrm{Ca}$ values in growth modeled shells from Kongsfjorden were recorded at the end of the mooring deployment in mid-September, whereas Rijpfjorden shells showed more variability, with maximum values occurring in the beginning of the mooring deployment (September to December) as well as towards the end of the mooring deployment (August to September, Figure 3). Coefficient of variation for minimum and maximum $\mathrm{Sr} / \mathrm{Ca}$ values was lower than those for $\mathrm{Mg} / \mathrm{Ca}$ (Table 3). Minimum Sr/Ca value was, on average, $1.32 \pm 0.04 \mathrm{mmol} \mathrm{mol}^{-1}$ (SE, $\mathrm{n}=30)$ and maximum value $2.37 \pm 0.09 \mathrm{mmol} \mathrm{mol}^{-1}(\mathrm{SE}, \mathrm{n}=30)$.

\subsection{5. $\mathrm{Mo} / \mathrm{Ca}$}

Molybdenum-to-calcium ratios were at their highest before or during the winter growth band in all shells analyzed for Mo/Ca (2009-2010) and the ratios decreased after the end of the growth check (Figures 3, B.11 B.14). After the minimum $\mathrm{Mo} / \mathrm{Ca}$, which occurred between mid-April and September in Kongsfjorden and between July and August in Rijpfjorden, Mo/Ca values increased again until the end of the mooring exposure (mid-September 2010, Figures 3 
340 mooring deployment (September to April, Figure 3].

\subsection{6. $\mathrm{Ba} / \mathrm{Ca}$}

Barium-to-calcium profiles were characterized by abrupt unimodal peaks (maximum values $=3.1-76.1 \mathrm{\mu mol} \mathrm{mol}^{-1}, \bar{x}=20.0 \mathrm{mmol} \mathrm{mol}^{-1}$, Table 5 that

345 were differentiated from low Ba/Ca background levels $\left(0.43-2 \mathrm{\mu mol} \mathrm{mol}^{-1}, \bar{x}\right.$ $=1 \mathrm{umol} \mathrm{mol}^{-1}$, Figures 3 , B.9 B.14. The peaks appeared annually, occurring subsequent to the winter growth band in 27 of 30 analyzed shells (Figures B.9 B.14. A distinct barium peak was not present in two C. ciliatum from 2007-2008 deployed in the $25 \mathrm{~m}$ basket in Rijpfjorden (Figure B.10) and one $C$. ciliatum from 2009-2010 deployed in the 15 m basket in Kongsfjorden (Figure B.11). In 2009-2010 samples, the Ba maxima was considerably lower in the 25 $\mathrm{m}$ basket in Rijpfjorden compared to other baskets (RB in Table 3 and Figure B.14. Barium peak values were not consistent within a basket as indicated by high coefficient of variation (Table 3). The minimum Ba/Ca values were associ-

\subsection{Ontogenic effects on minimum and maximum element ratios}

The analysis of relative importance of regressors indicated that fjord and basket where the bivalves were grown was the most important factor to explain variability in minimum and maximum element-to-calcium ratios (Figure 4. The length of growth increment during mooring deployment was an important factor to explain total variation, especially for $\mathrm{Li} / \mathrm{Sr}$ and $\mathrm{Sr} / \mathrm{Ca}$. Bivalve age contributed little to the total coefficient of determination in most cases, $\mathrm{R}^{2}$ values varying from 0.01 to 0.17 . Age of bivalves used in this study ranged from 4 to 10 years. 
3.4. Correlations between element ratios, growth rates and mooring instrument data

$\mathrm{Li} / \mathrm{Ca}$ and $\mathrm{Mg} / \mathrm{Ca}$ covaried within 2009-2010 shells as indicated by arrows pointing approximately to the same direction in the PCA plot (Figure 5B) and high correlation coefficients [mean for all samples $\left(r_{z}\right)=0.78$, correlation coefficient among samples $(r)=0.13-0.92$; Table B.9. Similar correlations between element ratios were evident for $\mathrm{Sr} / \mathrm{Ca}$ and $\mathrm{Mo} / \mathrm{Ca}$ in 2009-2010 (Figure 5B, $r_{z}$ $=0.59, \mathrm{r}=-0.69-0.99), \mathrm{Mn} / \mathrm{Ca}$ and $\mathrm{Ba} / \mathrm{Ca}$ - especially in the growth modeled shells (Figure 5C, $r_{z}=0.50, \mathrm{r}=-0.02-0.78$ ), and $\mathrm{Mg} / \mathrm{Ca}$ and $\mathrm{Mn} / \mathrm{Ca}$ in 2007-2008 shells (Figure 5A, $r_{z}=0.38, \mathrm{r}=-0.31-0.78$ ). Further, $\mathrm{Mg} / \mathrm{Ca}$ and $\mathrm{Li} / \mathrm{Mg}$ were strongly negatively correlated in 2009-2010 shells as demonstrated by arrows pointing to opposite directions in the PCA plot (Figure 5B, $\left.r_{z}=-0.92, \mathrm{r}=-0.99--0.60\right) . \mathrm{Li} / \mathrm{Sr}$ and $\mathrm{Mo} / \mathrm{Ca}$ demonstrated similar negative correlations (Figure $5 \mathrm{~B}, r_{z}=-0.66$ ). Also $\mathrm{Li} / \mathrm{Ca}$ and $\mathrm{Li} / \mathrm{Mg}, \mathrm{Mg} / \mathrm{Ca}$ and $\mathrm{Mo} / \mathrm{Ca}$, and $\mathrm{Li} / \mathrm{Ca}$ and Mo/Ca were negatively correlated (Table B.9. Temperature and salinity were negatively correlated $\left(r_{z}=-0.71, \mathrm{r}=-0.86-0.57\right)$, whereas temperature yielded positive correlations with fluorescence $\left(r_{z}=0.48\right.$, $\mathrm{r}=0.34-0.67)$ and logarithm of shell growth rate $\left(r_{z}=0.43, \mathrm{r}=0.22-0.66\right.$, Figure 5D).

Overall, logarithm of growth rate was the best explanatory factor for element ratio variability in growth modeled shells (Figure 6A, Table B.7). Coefficient of determination $\left(\mathrm{R}^{2}\right)$ for individual samples ranged between 0.19 and 0.75 for regressions between $\mathrm{Li} / \mathrm{Ca}$ and growth rate, between 0.30 and 0.59 for $\mathrm{Mg} / \mathrm{Ca}$, between 0.11 and 0.24 for $\mathrm{Li} / \mathrm{Mg}$, between 0.02 and 0.52 for $\mathrm{Li} / \mathrm{Sr}$, and between 0.01 and 0.87 for Mn/Ca (Table B.8). Also Sr/Ca exhibited significant correlations with growth rate, but these relationships varied from positive to negative (Table B.8. Temperature yielded significant slopes for the regression lines with $\mathrm{Li} / \mathrm{Ca}, \mathrm{Mg} / \mathrm{Ca}, \mathrm{Li} / \mathrm{Mg}$, and $\mathrm{Sr} / \mathrm{Ca}$ (Table B.8), but in the majority of samples these correlations were not as strong as those for logarithm of growth rate (Figure 6A). Notably temperature did not yield significant regressions with Li/Sr (Figure6B, Table B.8). Temperature relationships for $\mathrm{Li} / \mathrm{Ca}, \mathrm{Mg} / \mathrm{Ca}$ and 

residual standard error (Tables B.7. B.8.

\section{Discussion}

Barium-, manganese-, molybdenum-, and lithium-to-calcium ratios have previously been related to primary production (Fig. 4 in Vihtakari, 2014, Section 4.1). Although $\mathrm{Mn} / \mathrm{Ca}$ and $\mathrm{Ba} / \mathrm{Ca}$ exhibited patterns that resembled the patterns of the fluorescence index (Figure 3), which was used as a proxy of primary production, the differences in peak heights among samples from the same basket suggested that these element ratios were also affected by other processes and could not be used as unequivocal proxies of primary production (Tables 35 in the bivalve shells of each basket, but the timing varied among specimens in different baskets occurring 11 to 81 days after the phytoplankton bloom (Figure 3. Table 5. Section 4.3. Ba/Ca could potentially be related to dissolved or particular Ba in ambient seawater (Gillikin et al. 2006). Mo/Ca and Li/Ca did not exhibit patterns linked to primary production (Figure 3).

Lithium-, magnesium- and strontium-to-calcium ratios, in turn, have been „suggested as proxies of growth rate or temperature (Klein et al., 1996, Richardson, 2004, Pearce and Mann, 2006; Thébault et al., 2009b; Thébault and Chauvaud, 2013) (Section 4.2). We did observe similar patterns between Li/Ca, $\mathrm{Mg} / \mathrm{Ca}$, growth rate and temperature (Figures 56 6), but individual samples from the same basket demonstrated variability in element-to-calcium ratios, making it difficult to use these ratios as proxies of absolute shell growth rate or temperature (see Section 4.2, Figures 7 8). Finally, specimens from the same baskets demonstrated variability in $\mathrm{Sr} / \mathrm{Ca}$ profiles that could not satisfactorily be explained by any single predictor variable (growth rate, temperature, fluorescence and salinity) used in this study (Figure 6).

In general, our results highlight the limitations caused by metabolically controlled deposition of $\mathrm{CaCO}_{3}$ in bivalves (Checa, 2000, Schöne, 2008), suggesting 
that none of the studied element ratios could be used as unequivocal proxies of temperature, salinity, paleoproductivity or shell growth rate. In following sections we discuss the studied element ratios as potential proxies of primary production (Section 4.1), shell growth rate or temperature (Section 4.2), and sub-seasonal temporal anchors (Section 4.3). We also highlight the methodological constraints associated with our data (Section 4.4).

\subsection{Potential proxies of primary production}

Barium-to-calcium profiles were characterized by distinct unimodal peaks, which resembled the peaks in the fluorescence index (Figures 2,3 , B.9 B.14). The barium peak in Kongsfjorden shells occurred approximately 74 days after the phytoplankton peak, which took place in mid-May, and 19 days after the ice-algae/phytoplankton associated fluorescence peak in Rijpfjorden (Table 5). Gillikin et al. (2008) reported a comparable 40-day lag between phytoplankton bloom and shell $\mathrm{Ba} / \mathrm{Ca}$ peak in the great scallop (Pecten maximus). Dissolved barium from seawater, which in turn is sometimes connected with phytoplankton blooms (Fisher et al., 1991, Barats et al., 2009), has been found to be consistently incorporated into the calcitic blue mussel (Mytilus edulis) and great scallop as well as aragonitic Saxidoumus giganteus shells with a partition coefficient of approximately 0.1 (Gillikin et al., 2006, 2008: Tabouret et al., 2012). Applied to our shells, $\mathrm{Ba} / \mathrm{Ca}$ values should have been approximately similar within the averaging error framework (see Section 4.4), in each basket assuming that calcium was uniformly distributed along studied shells. This expectation was supported by the Ba/Ca background values, but not by the peak values: The background values varied between 0.4 and $\sim 2 \mu \mathrm{mol} \mathrm{mol}{ }^{-1}$ being consistent with those reported earlier (Barats et al. 2009), and did not show any obvious variation within baskets that could not have been explained by averaging error (Table 3). Measured maximum $\mathrm{Ba} / \mathrm{Ca}$ values, on the other hand, varied between 3.1-76.1 $\mathrm{umol} \mathrm{mol}^{-1}$, demonstrating different peak values among shells from a same basket (Table 3). This variability in maximum values is among the largest reported (Barats et al. 2009, Marali et al. 2015), and cannot be 
explained by averaging error (see Section 4.4).

Our results are inconclusive about the environmental factors associated with the observed barium peaks: Predictor variables did not satisfactorily explain the $\mathrm{Ba} / \mathrm{Ca}$ peaks. Although $\mathrm{Ba} / \mathrm{Ca}$ peaks occurred simultaneously with increased shell growth in all growth modeled shells (Figures 3. B.20), growth rate explained only $2 \%$ of $\mathrm{Ba} / \mathrm{Ca}$ variation across samples (marginal $\mathrm{R}^{2}$ from LMM; ${ }_{465}$ Figure 6) and $<1$ to $18 \%$ among samples $\left(\mathrm{R}^{2}\right.$ from regression models; Table B.8. Further, temperature was negatively related to $\mathrm{Ba} / \mathrm{Ca}$ explaining $2 \%$ of variation across samples (Figure 6). Bivalve age, shell height, or length of the growth increment during mooring deployment did not yield significant slopes in a regression model with $\mathrm{Ba} / \mathrm{Ca}$ peak values, and demonstrated fairly low relative importance compared to growth location (Figure 4). Finally, Ba/Ca peak values were significantly lower in specimens of the $25 \mathrm{~m}$ basket in Rijpfjorden compared to those of other baskets. Even though our results cannot exclude the possibility that $\mathrm{Ba} / \mathrm{Ca}$ peaks in bivalve shells might be connected to processes related to primary production, the considerable differences in $\mathrm{Ba} / \mathrm{Ca}$ maximums among samples from same basket and the variable time-lag between the phytoplankton bloom and the signal in the shell (Table 5 strongly suggest that the ratio cannot be used as a direct paleoproductivity proxy - in agreement with recent studies (Gillikin et al., 2008, Barats et al., 2009, Tabouret et al., 2012, Goodwin et al. 2013; Zhao et al., 2015).

In addition to barium, manganese-to-calcium profiles also demonstrated peaks that resembled the fluorescence index peaks (Figures 2 , 3, B.9, B.14). Despite the seemingly synchronous deposition of $\mathrm{Mn}$ in growth modeled shells (Table 4), Mn/Ca patterns exhibited individual differences among shells from same basket (Table 3). Further, Mn/Ca values in the growth modeled shells were clearly correlated with growth rate (Figure 6, Table B.8. Bivalve shell formation through transient precursor phases, such as amorphous $\mathrm{CaCO}_{3}$, allows incorporation of $\mathrm{Mn}$ in substantial concentrations due to a change in local symmetry of aragonite lattice (Soldati et al. 2016). A varying amount of $\mathrm{Mn}^{2+}$ bound to the $\mathrm{CaCO}_{3}$ matrix during shell formation or Mn not directly bound 
to the $\mathrm{CaCO}_{3}$ matrix, as suggested by Takesue et al. (2008), could explain the mixed $\mathrm{Mn} / \mathrm{Ca}$ results in our study. Nevertheless, Mn/Ca peaks occurring approximately simultaneously in growth modeled shells also demonstrate a degree of synchronous environmental or physiological control. Previous studies suggest that $\mathrm{Mn} / \mathrm{Ca}$ could be incorporated in relationship with Mn concentration in seawater (Freitas et al., 2006, Barats et al., 2008). Phytoplankton blooms have also been suggested as a cause for Mn fluctuations in bivalve shells (Vander Putten et al., 2000, Carroll et al., 2009). Our data do not support the direct connection with phytoplankton blooms, but it is possible that pelagic Mn cycle is connected to productivity to some extent, as reviewed by Barats et al. (2008). Consequently, $\mathrm{Mn} / \mathrm{Ca}$ is a potential but complicated proxy of several environmental and physiological factors in both species.

Maximum molybdenum-to-calcium values were measured in shell portions deposited at the beginning of fall in all growth modeled shells (Figure 3). Our dataset did not demonstrate prominent Mo peaks during spring, as has been reported for calcitic scallops Decatopecten radula (Thébault et al. 2009a) and P. maximus (Barats et al. 2010). Nevertheless, Mo/Ca profiles were relatively similar among shells demonstrating that the incorporation mechanism could have been environmentally regulated. The incorporation of Mo into bivalve shells might occur through diet, which makes $\mathrm{Mo} / \mathrm{Ca}$ a promising environmental proxy (Barats et al. 2010, Tabouret et al. 2012). If this was the case, local phytoplankton may not have been enriched in Mo. Alternatively, Mo could be connected to sediment surface redox-processes (Tribovillard et al., 2006) or sediment particles, as bivalves in our study were deployed in the water column and did not grow in their natural habitat. Although our results do not preclude the possibility for Mo/Ca being a potential proxy in S. groenlandicus and C. ciliatum, more research is needed to draw further conclusions about this elemental ratio.

Our data did not demonstrate a clear connection between the fluorescence index and Li/Ca (Figures 6, B.15 casting doubt on the hypothesis of phytoplank${ }_{520}$ ton blooms causing Li/Ca peaks (Thébault and Chauvaud, 2013). Therefore, 
Li/Ca peaks cannot be used as a proxy of timing and magnitude of phytoplankton blooms in our species, although it is possible that phytoplankton blooms could have contributed to the increase in the $\mathrm{Li} / \mathrm{Ca}$ values in Kongsfjorden (Table B.8).

\subsection{Potential proxies of shell growth rate or temperature}

Lithium-to-calcium patterns were similar among individuals in baskets, suggesting synchronized responses to environmental or physiological processes (Table 3 and Figure 3). The logarithm of average growth rate explained $43 \%$ of overall $\mathrm{Li} / \mathrm{Ca}$ variation across all samples (LMM, Figure6) and 19-75 \% among samples (regressions, Table B.8). Li/Ca-shell growth rate relationships were logarithmic, unlike in previous published studies where the authors reported linear relationships with a similar slope, but different intercept for $P$. maximus (Thébault and Chauvaud, 2013) and ocean quahog (Arctica islandica) (Thébault et al., 2009b) (Figure 7A). Shell growth rate can be an indicator 535 of crystal growth rate in bivalve mollusk shells (Lorrain et al., 2004, Gabitov et al., 2011; Thébault and Chauvaud, 2013). Consequently, the positive correlations between $\mathrm{Li} / \mathrm{Ca}$ and shell growth rate in this study agree with other published studies suggesting that crystal growth rate could be an important primary driver of Li/Ca incorporation in bivalve mollusk shells (Thébault et al. 2009b; Thébault and Chauvaud, 2013). Nevertheless, studies report different regression equations between $\mathrm{Li} / \mathrm{Ca}$ and shell growth rate and these relationships do not yield particularly high $\mathrm{R}^{2}$ values (Figure $7 \mathrm{~A}$ ). This suggests that other factors also affect $\mathrm{Li} / \mathrm{Ca}$ incorporation.

Temperature and riverine input have been suggested to partly control Li/Ca in bivalve shells (Thébault et al. 2009b; Thébault and Chauvaud, 2013). Since temperature and growth rate were correlated in our shells (Vihtakari et al. 2016), the effects of these factors are difficult to separate. Nevertheless, temperature significantly explained $\mathrm{Li} / \mathrm{Ca}$ variability, although these correlations were generally not as strong as for shell growth rate (Table B.8. Figures 677). 
perature correlations, as a one-month shift in $\mathrm{Li} / \mathrm{Ca}$ peak would have led to considerably stronger temperature correlations for Rijpfjorden shells (Figures 3 and B.15). Despite this, the relationships for species that have been studied so far do not appear to demonstrate strong enough $\mathrm{R}^{2}$ values to reconstruct seawater temperatures (Figure 7B). Instead, significant regressions between Li/Ca and temperature in bivalve mollusk shells (Figure 7B) could be explained by dependency between temperature and shell growth rate, and therefore $\mathrm{CaCO}_{3}$ crystal growth rate.

Since we lack elemental concentration measurements in seawater, we can only speculate about the effect of riverine input increasing Li concentration in ambient water and therefore contributing to shell $\mathrm{Li} / \mathrm{Ca}$ (Thébault et al. 2009b). Li/Ca peaks were coincident with decreased salinity (Figures 3 and B.15). If melt-water events increased $\mathrm{Li}$ concentration in ambient water, it is possible that these events could have contributed to Li/Ca fluctuations, as suggested by Thébault et al. (2009b). Despite the uncertainties in our dataset, we can conclude, with a relatively high certainty, that Li/Ca cannot be used as a temperature proxy in $S$. groenlandicus and $C$. ciliatum shells, but appears to be a promising proxy of shell and/or crystal growth rate. Li/Ca, however, did not yield strong enough relationships to precisely reconstruct sub-annual shell growth.

Relatively consistent patterns in $\mathrm{Mg} / \mathrm{Ca}$ among individuals from the same basket (Figures 3, B.9 B.14) suggested that the incorporation of $\mathrm{Mg} / \mathrm{Ca}$ is likely related to synchronized environmental or physiological factors. A large coefficient of variation, however, indicates that these processes do not yield similar $\mathrm{Mg} / \mathrm{Ca}$ peak values among shells (Table 3). Reasonably strong correlations with logarithm of average growth rate indicated that incorporation of $\mathrm{Mg} / \mathrm{Ca}$ could be related to shell precipitation rate similarly to Li/Ca (Figure6, Gabitov et al., 2011). Furthermore, $\mathrm{Mg} / \mathrm{Ca}$ correlated positively with temperature (Table B.8. Figure 6). Many studies have reported similar significant correlations between $\mathrm{Mg} / \mathrm{Ca}$ ratio and sea surface temperature (Dodd, 1965, Klein et al. 1996, Lazareth et al., 2003, Richardson, 2004; Freitas et al., 2005, Pearce and 
Mann, 2006; Wanamaker et al., 2008, Freitas et al., 2009, 2012, Schöne et al.

2011). Most of these studies report either a large variability in temperature correlations similar to our study (e.g. Richardson, 2004, Schöne et al., 2011), 2005 Wanamaker et al. 2008). Magnesium bound to organic matter in biogenic $\mathrm{CaCO}_{3}$ matrix can interfere with paleoenviromental signals in $\mathrm{Mg} / \mathrm{Ca}$ (Schöne et al., 2010). Consequently, organic matter has been removed prior to elemental analysis in some studies that have reported strong relationships between temperature and $\mathrm{Mg} / \mathrm{Ca}$ (Klein et al., 1996, 1997).

The ratio of $\mathrm{Mg} / \mathrm{Ca}$ is inversely correlated with temperature in abiogenic aragonite (Gaetani and Cohen, 2006), while the opposite is true for abiogenic calcite (Oomori et al. 1987). Despite this, the $\mathrm{Mg} / \mathrm{Ca}$ in studied aragonitic bivalve shells demonstrated significantly positive, although weak, relationships with temperature (Figure 8, Table B.8). Crystal kinetics, on the other hand, yield positive correlations with $\mathrm{Mg} / \mathrm{Ca}$ in abiogenic aragonite Gabitov et al. 2011), and could have driven the $\mathrm{Mg} / \mathrm{Ca}$ incorporation as indicated by strong correlations with logarithm of growth rate (Figure 6) assuming that shell and ${ }_{1} \mathrm{CaCO}_{3}$ crystal growth rate were correlated. Similarly to our results, Pearce and ${ }_{600}$ Mann (2006) reported positive $\mathrm{Mg} / \mathrm{Ca}$-temperature relationship for an aragonitic bivalve Ensis siliqua, whereas Schöne et al. (2011) found the expected negative relationship for Arctica islandica. Our $\mathrm{Mg} / \mathrm{Ca}$-temperature relationships had reasonably similar slope and intercept to those reported for calcitic bivalves Mytilus trossulus (Klein et al. 1996), M. edulis (Freitas et al., 2008), ${ }_{05}$ and $P$. maximus (Freitas et al. 2012), with the exception that coefficients of variation were clearly lower in our study (Figure 8). $\mathrm{Mg} / \mathrm{Ca}$-temperature relationships appear generally stronger for calcitic bivalves (Figure 8) than for aragonitic bivalves, possibly because $\mathrm{Mg}$ can be better accommodated in the crystal lattice of calcite than aragonite (Soldati et al., 2016). Nevertheless, reported $\mathrm{Mg} / \mathrm{Ca}$-temperature relationships vary between locations and studies for same calcitic species (Figure 8).

Magnesium-to-calcium is thought to be strongly metabolically controlled in 
marine bivalves: present day $\mathrm{Mg} / \mathrm{Ca}$ molar ratio is $5.2 \mathrm{~mol} \mathrm{~mol}^{-1}$ Stanley and Hardie, 1998), while $\mathrm{Mg} / \mathrm{Ca}$ ratios in bivalve $\mathrm{CaCO}_{3}$ are several orders of magnitude lower than the ambient molar ratios (varied between 0.0004 and 0.0041 mol mol${ }^{-1}$ in this study). Varying metabolic control depending on species, population, condition of individuals and time of the year, together with temperature, differing ambient $\mathrm{Mg}$ concentrations and potential kinetic effects, seem to affect $\mathrm{Mg} / \mathrm{Ca}$ incorporation into bivalve shells. Even though $\mathrm{Mg} / \mathrm{Ca}$ may function as a local temperature proxy in some calcitic bivalve shells (Figure 8), $\mathrm{Mg} / \mathrm{Ca}$ incorporation is often influenced by several factors, leading to a proxy-derived imprecision larger than the seasonal temperature fluctuations. Our results are an example of such imprecision and indicate that $\mathrm{Mg} / \mathrm{Ca}$ is an unreliable temperature proxy for $S$. groenlandicus and C. ciliatum. Nevertheless, our results also indicate that temperature does correlate with $\mathrm{Mg}$ incorporation, and further studies should consider removal of organic matter before ICP-MS analyses as also suggested by Schöne et al. (2010).

Studies on deep-sea corals have demonstrated that combining $\mathrm{Li} / \mathrm{Ca}$ and $\mathrm{Mg} / \mathrm{Ca}$ could potentially be used to tease apart the metabolic effects associated with these ratios and strengthen the temperature relationship (Case et al., 2010). Similar results have been presented for $\mathrm{Li} / \mathrm{Sr}$ in shells of the bivalve Cerastoderma edule (Füllenbach et al. 2015). Our results, however, demonstrated generally weaker correlations between $\mathrm{Li} / \mathrm{Mg}$ or $\mathrm{Li} / \mathrm{Sr}$ and temperature than those between $\mathrm{Li} / \mathrm{Ca}$ and temperature, $\mathrm{Mg} / \mathrm{Ca}$ and temperature, and $\mathrm{Sr} / \mathrm{Ca}$ and temperature separately (Figure 6. Table B.8). Consequently, either Li/Mg or $\mathrm{Li} / \mathrm{Sr}$ do not provide a robust temperature proxy in the studied species.

Strontium-to-calcium ratio was significantly affected by all predictor variables (Figure 6), temperature and fluorescence index yielding the most consistent regressions (Table B.8. Strontium partition into calcium carbonate is 640 related to the precipitation rate of $\mathrm{CaCO}_{3}$ matrix (Lorens, 1981: Carpenter and Lohmann, 1992, Gaetani and Cohen, 2006), but also to ambient Sr concentration and temperature (Lorens and Bender, 1980; Zhao et al., 2015). There are no seasonal seawater element concentration data available for the Svalbard area, 
and therefore we cannot dismiss the possibility of ambient Sr concentrations interfering with possible temperature signal in $\mathrm{Sr} / \mathrm{Ca}$ in studied shells. Coefficient of variation for $\mathrm{Sr} / \mathrm{Ca}$ maximum values, however, indicated that $\mathrm{Sr} / \mathrm{Ca}$ values varied among samples from same basket (Table 3). The large variability in $\mathrm{Sr} / \mathrm{Ca}$ among samples from the same location is consistent with the literature (Lazareth et al., 2003, Gillikin et al., 2005, Poulain et al., 2015) and suggests that any environmental signals in Sr/Ca may be difficult to separate from vital effects. Although, some studies have successfully used Sr/Ca as a temperature proxy (Dodd, 1965, Richardson, 2004; Yan et al., 2013, Zhao et al., 2015), other studies question the relationship (Vander Putten et al., 2000, Gillikin et al., 2005, Carré et al., 2006, Saenger et al., 2008, Schöne et al., 2013). Our results

655 demonstrated weak negative $\mathrm{Sr} / \mathrm{Ca}$ correlations with shell growth rate and weak positive correlations with temperature (Figure 6). Since temperature and shell growth rate were correlated (Figure 5), it is possible that these factors worked against each other thereby reducing $\mathrm{R}^{2}$ values between temperature and $\mathrm{Sr} / \mathrm{Ca}$ (Figure 3, Table B.8. Even so, the relationships between $\mathrm{Sr} / \mathrm{Ca}$ and temperature or crystal kinetics for abiogenic aragonite (Gaetani and Cohen, 2006) are the opposite to what we observed. This is a strong indication of metabolic control in studied shells, assuming that shell and crystal growth rate were correlated. Such conflicting correlations and large variability of peak values in our data (Table 3) indicate that $\mathrm{Sr} / \mathrm{Ca}$ cannot be used as a temperature proxy for studied shells.

\subsection{Sub-seasonal temporal anchors}

Barium-to-calcium maximum values were deposited at approximately the same time among samples from the same basket (Table 5) considering the uncertainty caused by LA-ICP-MS averaging error and growth models derived from $\delta^{18} \mathrm{O}$ values (see Section 4.4). Measured Ba/Ca maxima were estimated to be deposited in mid-July to early August in Kongsfjorden (Table 5). Barium peaks in Rijpfjorden occurred during or immediately after a fast shell growth period (Figures 3, B.20) and were timed to occur in early July in the basket at 
$15 \mathrm{~m}$ depth and late July, 12 days later, in the deeper basket at $25 \mathrm{~m}$ (Table

675 5). Simultaneous occurrence of $\mathrm{Ba} / \mathrm{Ca}$ maximums within baskets and similar patterns in 29 of 32 analyzed shells (Figure B.9 B.14 indicates synchronous environmental or physiological drivers for incorporation of $\mathrm{Ba}$ in studied shells. Synchronously deposited chemical proxies are useful temporal anchors to combine chronologies across bivalves sampled from the same location (Marali et al.

680 2015). Our results indicate that the Ba/Ca peaks are likely to occur simultaneously 2.5 weeks to 2.5 months after primary production blooms. Similar results have been reported elsewhere (Gillikin et al., 2008, Marali et al., 2015) and indicate that $\mathrm{Ba} / \mathrm{Ca}$ peaks can be used as sub-annual anchors across shells from a same location, if averaging error of elemental sampling is kept sufficiently low.

$\mathrm{Li} / \mathrm{Ca}$ also demonstrated remarkably synchronous patterns within baskets (Table 3) as minimum and maximum value variability could likely be explained by averaging error caused by LA-ICP-MS sampling (see Section 4.4. Therefore, $\mathrm{Li} / \mathrm{Ca}$ peak and trough values could have been approximately similar across individuals from a same basket, further demonstrating the synchronized occurrence of this element ratio. Overall, Li/Ca ratios corresponded with those reported by Thébault et al. (2009b): the range of $\mathrm{Li} / \mathrm{Ca}$ fluctuation they reported was 1.3 to 1.6 fold over a growing season, whereas lithium values in this study varied between 1.3 and 2.2 fold (1.6 on average). This demonstrates that Li/Ca could work as a temporal anchor also for other species than S. groenlandicus and $C$. ciliatum. Since Li/Ca peaks were rather broad in studied shells it is advisable to use the increases in $\mathrm{Li} / \mathrm{Ca}$ as temporal anchors.

\subsection{Methodological limitations}

The bivalves used in our study were held in the water column on oceanographic moorings without sediment, and therefore they might not have incorporated trace elemental impurities as they would do in their natural habitat. Age is known to influence element-to-calcium ratios bivalves record in their shells (Schöne et al., 2011). In the present study, ontogeny was not found to substantially affect element-to-calcium ratios (Figure 4), possibly due to the 
relatively young age of bivalves (4 to 10 years). Physiological factors related to mooring deployment and condition of individuals (Schöne, 2008) could have explained inconsistencies of element levels, but we could not separate such individual differences due to our experimental design. The mooring deployment likely excluded the effect of sediment-surface redox-processes, which have been suggested as important contributors for the seasonal dynamics of Mn, at least (Dehairs et al., 1989, Tribovillard et al., 2006, Barats et al., 2008, Thébault et al. 2009a). Further, we did not observe similar seasonal patterns in $\mathrm{Sr} / \mathrm{Ca}$ ratios that has been reported earlier for S. groenlandicus Ambrose et al. 2006, Carroll et al., 2009). It is possible that $\mathrm{Sr} / \mathrm{Ca}$ is partly connected with sediment surface processes and, therefore our shells did not record seasonal patterns in this element ratio. Alternatively, physiological stress could have disturbed the natural incorporation of this element.

Many elements are incorporated into bivalve shells either directly from ambient water or through food particles (Lorens and Bender, 1980; Tabouret et al. 2012 Zhao et al. 2015). The lack of data on seasonal element concentration in food particles is a limiting factor for paleoclimatic and paleoecological studies. Seasonal fluctuations of studied elemental ratios in ambient water could partly explain the low correlations with temperature.

The extent of time-averaging sampled by LA-ICP-MS is relative to the sample volume and average shell growth rate over the sampled area (Goodwin et al. 2004, Beelaerts et al. 2008). Because sample spot size in our study varied little within years (see Section 2.2), time averaging was related to shell growth rate. Even though LA-ICP-MS sampling was able to capture the $\mathrm{Ba} / \mathrm{Ca}$ peaks (Figures 3, B.9 B.14 it is possible that time-averaging contributed to profiles of some elements during low growth rate such that no meaningful environmental correlations were detected (Shirai et al., 2014).

Growth models used to determine the time extent for each LA-ICP-MS sample were subject to uncertainty (Vihtakari et al., 2016). It is unlikely that these growth models were an entirely accurate representation of the actual growth 
during the mooring deployment and, therefore, our dataset contained a bias.

This could lead to elevated correlations between element ratios and average shell growth rate because shell growth rate was obtained from growth models which affected the alignment of elemental ratios. Further, shell growth rate and temperature were significantly correlated in all growth modeled shells (Figure 740 5. Vihtakari et al. 2016).

Even though we attempted to keep LA-ICP-MS samples as close to the middle of the shell section as possible (Figure 1), non-linear growth patterns could have caused variations in the actual location of LA-ICP-MS samples hence affecting the element ratios (Lazareth et al., 2013). This is because the sample spot alignment method used in this study (Vihtakari, 2016) could not correct for measurement bias caused by variability in $\mathrm{CaCO}_{3}$ matrix. Shell microstructure, for instance, can influence elemental ratios (Schöne et al., 2010, 2013). Any element ratio variations caused by the microstructure essentially became averaged in our study due to relatively large sample spot diameter $(\bar{x}=87.5 \mu \mathrm{m}$ in 2009 2010), and could have introduced a bias to our measurements. Furthermore, the sample alignment method assumed two-dimensional sampling ignoring any effects of LA-ICP-MS sample volume. Consequently, the curvature of growth lines deeper in the sample could have increased imprecision of element ratios through three-dimensional time-averaging. Despite all these uncertainties, our extensive dataset clearly indicates that all of the studied elemental ratios were affected by several factors to the extent that no element ratio in this study could be used as an unequivocal proxy of temperature, salinity, fluorescence or shell growth rate.

\section{Conclusions}

We conclude that $\mathrm{Ba} / \mathrm{Ca}, \mathrm{Li} / \mathrm{Ca}$ and $\mathrm{Mg} / \mathrm{Ca}$ are potential environmental proxies in $S$. groenlandicus and $C$. ciliatum shells. Incorporation of Ba/Ca might be connected with seasonal dissolved or particular Ba dynamics in ambient water, and incorporation of $\mathrm{Li} / \mathrm{Ca}$ and $\mathrm{Mg} / \mathrm{Ca}$ is likely connected with 
both shell growth rate and seawater temperature. All studied element ratios

plicating the interpretation of element ratios. Our study was further affected by methodological constraints, such as time-averaging error, experimental artifacts, and uncertainties in sub-annual growth models, leading to partly inconclusive results for $\mathrm{Sr} / \mathrm{Ca}$ and $\mathrm{Mo} / \mathrm{Ca}$. Nevertheless, our results are an important contrithe studied elemental ratios can be used as unequivocal proxies of seawater temperature, salinity, paleoproductivity, or shell growth rate. This, however, does not preclude the use of element-to-calcium ratios as environmental proxies, but merely indicates that seasonal dynamics of elements in seawater, element content in potential food particles, and seasonal variations in bivalve metabolism must be understood better to link elemental ratios in bivalve mollusk shells to environmental processes.

\section{Acknowledgments}

We acknowledge the use of the NSF-supported WHOI ICP-MS facility and thank Scot Birdwhistell for his excellent assistance. We are grateful to Bates Imaging Center and William Ash for help with thick-section photographs. Further, we want to thank the Stack Exchange community for help with the graphical presentation and data-analysis, and the $\mathrm{R}$ community for maintaining open source statistics tools used in this study. This research was financed through the UiT The Arctic University of Norway Utenlandstipend (MV), the EU 7th Framework Program project Arctic Tipping Points (No. FP7-ENV-2009-226248, http://www.eu-atp.org, PER), the Research Council of Norway (No. 184719/S40, PER; No. 223259, MLC), the Norwegian Polar Institute (HH, MV) and Akvaplanniva (PER, MV, WGA, MLC). WGA is currently an employee of the US National Science Foundation, however, any opinions, findings, conclusions, or recommendations expressed in this article are those of WGA, and his co-authors, and do not reflect the views of the US National Science Foundation. 


\section{Figure captions}

Figure 1: Sampling schematics of S. groenlandicus and C. ciliatum shells. A) Bivalve shells were cut along the maximum growth axis (black line). B) Resulting cross-section of the shell for specimen E (S. groenlandicus from $15 \mathrm{~m}$ basket in Rijpfjorden). The growth increment during mooring deployment is highlighted using a black box. C) Light microscopy picture of thick-section of the growth during the mooring deployment showing a disturbance line formed during deployment (blue arrow), a prominent opaque winter growth line (red arrow), several weaker intra-annual growth lines, and LA-IPC-MS sampling spots targeted on the middle of

shell section between the inner and outer shell surface. Black arrow demonstrates the direction of growth (DoG). The figure is modified from Vihtakari et al. (2016).

Figure 2: Temperature, fluorescence index (FLI) and salinity during the study period. Kongsfjorden is plotted with a red line, while blue represents Rijpfjorden. The lighter hue illustrates instruments close to the $15 \mathrm{~m}$ baskets (15 m for temperature, $10-17 \mathrm{~m}$ for fluorescence and salinity; see Table 2 and the darker hue represents instruments adjacent to the $25 \mathrm{~m}$ baskets (25 $\mathrm{m}$ for temperature; $25-36 \mathrm{~m}$ for fluorescence and salinity). Grey bars indicate the time of sea-ice cover in Rijpfjorden.

Figure 3: Element-to-calcium ratios variability during the mooring deployment in growth modeled shells. Baskets are presented in columns and element ratios and predictor variables in rows. A) Kongsfjorden $25 \mathrm{~m}$ basket, B) Rijpfjorden $15 \mathrm{~m}$ basket, and C) Rijpfjorden 25 $\mathrm{m}$ basket. Element ratios from top: $\mathrm{Li} / \mathrm{Ca}$ (yellow), $\mathrm{Mg} / \mathrm{Ca}$ (red), $\mathrm{Mn} / \mathrm{Ca}$ (blue), $\mathrm{Sr} / \mathrm{Ca}$ (purple), Mo/Ca (orange), Ba/Ca (green). Solid lines represent S. groenlandicus and dotdashed lines $C$. ciliatum. Predictor variables are overlaid on top of each other. Growth rate is given as bars, temperature, salinity and fluorescence index as red, blue and green lines, respectively. Shading for element ratio panels illustrates the averaging error of LA-ICP-MS samples. Grey shading on the background represents the estimated average winter growth band for each basket (see Vihtakari et al. 2016). 
Figure 4: Relative importance of fjord and basket (black), bivalve age (grey) and growth increment length during mooring deployment (white) as predictor variables for minimum (A) and maximum (B) element-to-calcium ratios recorded during the mooring deployment. Bars indicate the explained variation $\left(\mathrm{R}^{2}, \mathrm{x}\right.$-axis) by all three predictor variables. Shades within each bar represent the variation explained by each of the predictor variables. The analysis includes all 2009-2010 bivalves.

Figure 5: Principal component analysis (PCA) on correlation matrices of A) element ratios in 2007-2008, B) element ratios in 2009-2010, C) averaged element ratios (= response variables for regression models) for shells with growth models in 2009-2010, and D) predictor variables for regression models $(\mathrm{GR}=$ logarithm of growth rate, $\mathrm{T}=$ temperature, $\mathrm{F}=$ fluorescence index, and $\mathrm{S}=$ salinity). Principal components were calculated with correlation coefficients averaged over samples using Fisher z-transformation (see Section 2.3. Coloring of variables is equal to Figure 3 See Table B.9 for detailed list of correlations.

Figure 6: Overall relationships between element ratios and predictor variables (Fixed effect: $\mathrm{GR}=$ logarithm of growth rate, $\mathrm{T}=$ temperature, $\mathrm{F}=$ fluorescence index, and $\mathrm{S}=$ salinity) estimated using linear mixed-effect models. A) Marginal coefficient of variation indicating the variation in an element ratio explained by a predictor variable across all samples. B) Relative effect (i.e. the slope using intercepts from the random effect) of predictor variables indicating the relative magnitude and direction of correlations. Error bars represent $95 \%$ confidence intervals (CIs) for relative effects. Relative effects are scaled to absolute value of maximum CI (see Appendix A. If a CI does not cross the horizontal line at 0 , the effect is significantly different from 0 at $95 \%$ confidence-level.

Figure 7: Regressions between bivalve shell $\mathrm{Li} / \mathrm{Ca}$ and A) shell growth rate, and B) temperature for S. groenlandicus and C. ciliatum (this study), as well as Pecten maximus (Thébault and Chauvaud 2013), Arctica islandica (Thébault et al. 2009b), and Cerastoderma edule (Füllenbach et al. 2015). Triangles illustrate measured values for S. groenlandicus and circles measured values for $C$. ciliatum. Relationships were logarithmic for S. groenlandicus and $C$. ciliatum in A. Regressions for P. maximus are for the year 2001. Regression equations for $S$. groenlandicus and C. ciliatum are presented in Table B.8.

Figure 8: Comparison of linear regressions between bivalve shell $\mathrm{Mg} / \mathrm{Ca}$ and temperature among studies $[1=$ this study, $2=$ Klein et al. (1996), $3=$ Vander Putten et al. (2000), $4=$ Richardson (2004), $5=$ Freitas et al. (2005), $6=$ Freitas et al. (2006), $7=$ Freitas et al. (2008), $8=$ Wanamaker et al. 2008) (all salinities), $9=$ Freitas et al. (2012)]. Triangles illustrate measured values for $S$. groenlandicus and circles measured values for C. ciliatum. Regression equations were extracted from Freitas et al. (2012). 


\section{Table captions}

Table 1: Total number of LA-ICP-MS analyzed bivalve specimens. Numbers in parentheses indicate the number of samples with growth models determined through SIMS $\delta^{18} \mathrm{O}$ measurements. Basket abbreviations used through out this study are specified in "Basket" column.

Table 2: Depths (m) of mooring instruments used to record environmental variables.

Table 3: Mean values $(\bar{x})$ and coefficient of variation $(\mathrm{CV})$ of maximum and minimum element ratios measured along shell sections. Year 2010 refers to the deployment period 2009-2010 and year 2008 to the deployment period 2007-2008. Number of samples is specified in " $n$ " column. See Table 1 for basket abbreviations.

Table 4: Manganese-to-calcium peaks and their relation to spring bloom peaks determined from fluorescence index for samples with growth models. Columns from the left: Sample $=$ sample IDs and basket averages corresponding to Vihtakari et al. (2016); Treatment = treatment basket, see Table 1 Species: $\mathrm{Ser}=S$. groenlandicus, and $\mathrm{Cil}=$ C. ciliatum; $\mathrm{Mn} / \mathrm{Ca} \max =$ maximum measured $\mathrm{Mn} / \mathrm{Ca}$ ratio; Timing of $\mathrm{Mn} / \mathrm{Ca}$ max $=$ estimated timing for the Mn/Ca peak using centroids, and minimum (Min) and maximum (Max) extent of a LA-ICP-MS spot. Minimum (Min) and maximum (Max) are expressed as days from the centroid; After fluorescence peak = indicating how many days after the spring bloom peak when the $\mathrm{Mn} / \mathrm{Ca}$ maximum took place.

Table 5: Barium-to-calcium peaks and their relation to spring bloom peaks determined from fluorescence index for samples with growth models. See Table 4 for legend.

\section{Appendix A. Mathematical formulae of regression models in subject- specific scalar form}

See Table A.6 and Section 2.3 for further information. 
Appendix A.1. Model 1

$$
Y_{i j}=\left(\beta_{0}+\beta_{x} X_{i j}\right)+b_{i 0}+E_{i j}, i=A, B, \ldots, I, j=1,2, \ldots, n_{i}
$$

800

Where $\mathrm{i}$ is the sample; $\mathrm{j}$ the $\mathrm{n}^{\text {th }}$ row for sample $\mathrm{i} ; Y_{i j}$ the element ratio for each $\mathrm{i}$ and $\mathbf{j} ; \beta_{0}$ the estimated common intercept across all $\mathrm{i}$ and $\mathbf{j} ; \beta_{x}$ the estimated common slope across all $\mathrm{i}$ and $\mathrm{j} ; X_{i j}$ the predictor variable (logarithm of growth rate, temperature, fluorescence index or salinity) value for each $\mathrm{i}$ and $\mathrm{j}$; $b_{i 0}$ the estimated random intercept for each i; and $E_{i j}$ the residuals for each i and $\mathrm{j}$.

Appendix A.2. Model 2

$\operatorname{Ln}\left(Y_{i j}\right)=\left(\beta_{0}+\beta_{G R} G R_{i j}+\beta_{T} T_{i j}+\beta_{F} F_{i j}+\beta_{S} S_{i j}\right)+b_{0}+E_{i j}, i=A, B, \ldots, I, j=1,2, \ldots, n_{i}$

Where $\beta_{G R}, \beta_{T}, \beta_{F}$, and $\beta_{S}$ are the estimated common slopes across all $\mathrm{i}$ and $\mathrm{j}$ for logarithm of growth rate, temperature, fluorescence index and salinity, respectively; $G R_{i j}, T_{i j}, F_{i j}$, and $S_{i j}$ the normalized and scaled values of predictor variables for row $\mathrm{j}$ of sample i. Arithmetic mean of GR, T, F, and $\mathrm{S}$ $($ columns covering all $\mathrm{i}$ and $\mathrm{j})=0$, and standard deviation $=1 . \beta_{G R}, \beta_{T}, \beta_{F}$, and $\beta_{S}$ were standardized to the maximum absolute value of their confidence intervals $(\mathrm{CI})$ :

$$
\text { Relative } \beta_{x}(\%)=\frac{\beta_{x}}{\max \left[\left|C I\left(\beta_{x}\right)\right|\right]} \times 100 \%
$$

Appendix A.3. Model 3

$$
Y_{j}=\beta_{0}+\beta_{x} X_{x j}+E_{j}, j=1,2, \ldots, n
$$

Where $Y_{j}$ is the element ratio value for $\mathrm{j}^{\text {th }}$ row, $X_{i j}$ the predictor variable (logarithm of growth rate, temperature, fluorescence index or salinity) value for 
each $\mathrm{i}$ and $\mathrm{j}, \beta_{0}$ the estimated intercept of the regression model, $\beta_{x}$ the estimated slope, and $E_{j}$ the residuals for each $\mathrm{j}$. The regressions were run for each sample separately.

Table A.6: Overview of models used to illustrate the relationships between element ratios in growth modeled shells and predictor variables $(\mathrm{GR}=$ logarithm of modeled growth rate, $\mathrm{T}=$ temperature, $\mathrm{F}=$ fluorescence index, and $\mathrm{S}=$ salinity). Predictor variables were averaged over the estimated temporal extent of each LA-ICP-MS sample using daily values. Columns from the left: Model number used in the text (see Section 2.3); Used analysis; Type of linear model $(\mathrm{LMM}=$ linear mixed-effect regression model. $\mathrm{LR}=$ linear regression model $)$; Definition of the model given in $\mathrm{R}$ notation $[\mathrm{x}=$ each predictor variable separately, $\mathrm{y}=$ element ratio used as a response variable $(\mathrm{Li} / \mathrm{Ca}, \mathrm{Mg} / \mathrm{Ca}, \mathrm{Mg} / \mathrm{Li}, \mathrm{Mn} / \mathrm{Ca}, \mathrm{Sr} / \mathrm{Ca}, \mathrm{Mo} / \mathrm{Ca}$ or $\mathrm{Ba} / \mathrm{Ca}$ )]; Transformations conducted before analysis; R functions used; Figures and tables where the results of an analysis are presented.

\section{Appendix B. Supplementary electronic data}

Figure B.9: Element to calcium ratios for Kongsfjorden 2007-2008 shells grown in the basket at $25 \mathrm{~m}$ depth. Horizontal error bars illustrate the estimated extent covered by a LA-ICP-MS sample along the distance axis. Grey shading illustrates the winter growth band.

Figure B.10: Element to calcium ratios for Rijpfjorden 2007-2008 shells grown in the basket at $25 \mathrm{~m}$ depth. See Figure B.9 for legend.

Figure B.11: Element to calcium ratios for Kongsfjorden 2009-2010 shells grown in the basket at $15 \mathrm{~m}$ depth. See Figure B.9 for legend.

Figure B.12: Element to calcium ratios for Kongsfjorden 2009-2010 shells grown in the basket at $25 \mathrm{~m}$ depth. See Figure B.9 for legend.

Figure B.13: Element to calcium ratios for Rijpfjorden 2009-2010 shells grown in the basket at $15 \mathrm{~m}$ depth. See Figure B.9 for legend. 
Figure B.14: Element to calcium ratios for Rijpfjorden 2009-2010 shells grown in the basket at $25 \mathrm{~m}$ depth. See Figure B.9 for legend.

Figure B.15: Weekly averages of Li/Ca (black line) and growth rate (gray bars) for individual samples together with temperature (red line), fluorescence index (green line) and salinity (blue line) for corresponding basket. Samples A-C are from Kongsfjorden $25 \mathrm{~m}$ basket, D-F from Rijpfjorden $15 \mathrm{~m}$ basket, and G-I from Rijpfjorden $25 \mathrm{~m}$ basket. C, F, and $\mathbf{I}$ are C. ciliatum, the rest $S$. groenlandicus. Black dots represent the centroids of LA-ICP-MS samples, gray shading and horizontal error bars the averaging error. Dashed vertical lines illustrate the estimated extent of the winter growth band. Variables are scaled to $\mathrm{Li} / \mathrm{Ca}$.

Figure B.16: Weekly averages of $\mathrm{Mg} / \mathrm{Ca}$ (black line) for individual samples. See Figure B.15 for legend.

Figure B.17: Weekly averages of $\mathrm{Mn} / \mathrm{Ca}$ (black line) for individual samples. See Figure B.15 for legend.

Figure B.18: Weekly averages of $\mathrm{Sr} / \mathrm{Ca}$ (black line) for individual samples. See Figure B.15 for legend.

Figure B.19: Weekly averages of Mo/Ca (black line) for individual samples. See Figure B.15 for legend.

Figure B.20: Weekly averages of Ba/Ca (black line) for individual samples. See Figure B.15 for legend. 
Table B.7: Linear mixed effect regression parameters between element ratio and a single fixed effect. Columns from the left: Ratio $=$ element ratio; Fixef $=$ fixed effect $($ see Table A.6; $\mathrm{Par}=$ regression parameter $(\mathrm{Int}=$ intercept and $\mathrm{Sl}=$ slope $)$; Fixed effects $=$ estimated value (Est) and $95 \%$ confidence intervals (Min and Max) for corresponding regression parameter. $\mathrm{R}^{2}=$ Marginal (Marg) and conditional (Cond) coefficient of determination explaining the proportion of variance explained by the fixed effect alone and by both the fixed effect and random effect, respectively; Standard error $=$ random effect $(=$ Sample, Rand $)$ and residual (Res) mean standard error.

Table B.8: Linear regressions between element ratios (Ratio) and logarithm of growth rate (GR), temperature (T), fluorescence (F), and salinity (S) fitted separately for each predictor variable and sample. Sample IDs correspond to Tables 45 and "Clino", "Ser", and "all" refer to regression models fitted on C. ciliatum, S. groenlandicus, and all data respectively. Intercepts, slopes and coefficients of determination are presented in Intercept, Slope and $\mathrm{R}^{2}$ columns, respectively. Slopes with $\mathrm{p}<0.05$ are indicated with bold font. Intercepts and slopes are relative to the unit in brackets after an element ratio.

Table B.9: Pearson correlations between element ratios (A-C) and predictor variables (D) calculated using average correlation coefficients for samples. Columns from the left: correlation pair, group (refers to Figure 5), number of averages used as number of observations, $\mathrm{r}_{z}=$ averaged correlation coefficient after Fisher z-transformation, $\mathrm{r}_{\min }$ and $\mathrm{r}_{\max }$ minimum and maximum correlation coefficients among $\mathrm{n}$. 


\section{References}

Ambrose, W.G., Carroll, M.L., Greenacre, M.J., Thorrold, S.R., McMahon, K.W., 2006. Variation in Serripes groenlandicus (Bivalvia) growth in a Norwegian high-Arctic fjord: evidence for local- and large-scale climatic forcing. Glob. Chang. Biol. 12, 1595-1607. URL:

Ambrose, W.G., Clough, L.M., Johnson, J.C., Greenacre, M., Griffith, D.C.,

Carroll, M.L., Whiting, A., 2014. Interpreting environmental change in coastal Alaska using traditional and scientific ecological knowledge. Front.

口 Mar. Sci. 1, 1-15. URL: http://journal.frontiersin.org/article/10. 3389/fmars.2014.00040/abstract, doi 10.3389/fmars.2014.00040

Ambrose, W.G., Renaud, P.E., Locke, W.L., Cottier, F.R., Berge, J., Carroll, M.L., Levin, B., Ryan, S., 2012. Growth line deposition and variability in growth of two circumpolar bivalves (Serripes groenlandicus, and Clinocardium ciliatum). Polar Biol. 35, 345-354. URL: http://link.springer.com/10. 1007/s00300-011-1080-4, doi 10.1007/s00300-011-1080-4.

Barats, A., Amouroux, D., Chauvaud, L., 2010. Spring molybdenum enrichment in scallop shells: a potential tracer of diatom productivity in temperate coastal

q environments (Brittany, NW France). Biogeosciences 7, 233-245. URL: http: //hal.ird.fr/hal-00484898/.

Barats, A., Amouroux, D., Chauvaud, L., Pécheyran, C., Lorrain, A., Thébault, J., Church, T.M., Donard, O.F.X., 2009. High frequency Barium profiles in shells of the Great Scallop Pecten maximus: a methodical long-term and q multi-site survey in Western Europe. Biogeosciences 6, 157-170. URL: http: //www.biogeosciences.net/6/157/2009/, doi:10.5194/bg-6-157-2009.

Barats, A., Amouroux, D., Pécheyran, C., Chauvaud, L., Donard, O.F.X., 2008. High-frequency archives of manganese inputs to coastal waters (Bay of Seine, 
France) resolved by the LA-ICP-MS analysis of calcitic growth layers along scallop shells (Pecten maximus). Environ. Sci. Technol. 42, 86-92. URL: http://www.ncbi.nlm.nih.gov/pubmed/18350880

Barton, K., 2014. MuMIn: Multi-model inference. R package version 1.10.5. URL: http://cran.r-project.org/package=MuMIn.

Beelaerts, V., Ridder, F., Schmitz, N., Bauwens, M., Dehairs, F., Schoukens, J., Pintelon, R., 2008. On the elimination of bias averaging-errors in proxy a records. Math. Geosci. 41, 129-144. URL: http://www.springerlink.com/ index/10.1007/s11004-008-9193-1, doi 10.1007/s11004-008-9193-1.

Bonett, D.G., Wright, T.A., 2000. Sample size requirements for estimating Pearson, Kendall and Spearman correlations. Psychometrika 65, 2328. URL: http://link.springer.com/10.1007/BF02294183, doi 10.1007/ BF02294183.

Butler, P.G., Wanamaker, A.D., Scourse, J.D., Richardson, C.A., Reynolds, D.J., 2013. Variability of marine climate on the North Icelandic Shelf in a 1357-year proxy archive based on growth increments in the bivalve Arctica islandica. Palaeogeogr. Palaeoclimatol. Palaeoecol. 373, 141-151. URL: http://dx.doi.org/10.1016/j.palaeo.2012.01.016, doi:10.1016/ j.palaeo.2012.01.016.

Carpenter, S.J., Lohmann, K.C., 1992. Sr/Mg ratios of modern ma870 rine calcite: Empirical indicators of ocean chemistry and precipitation rate. Geochim. Cosmochim. Acta 56, 1837-1849. URL:

a http://wWw.sciencedirect.com/science/article/B6V66-488Y200-7F/ 2/5aa75c3b18efe15dafbe5aa4d404c828

Carré, M., Bentaleb, I., Bruguier, O., Ordinola, E., Barrett, N., Fontugne, M., 875 2006. Calcification rate influence on trace element concentrations in aragonitic bivalve shells: Evidences and mechanisms. Geochim. Cosmochim. Acta

口 70, 4906-4920. URL: http://linkinghub.elsevier.com/retrieve/pii/ S0016703706019053, doi $10.1016 /$ j.gca.2006.07.019. 
Carroll, M.L., Ambrose Jr, W.G., Levin, B.S., Locke V, W.L., Henkes, G.A., Hop, H., Renaud, P.E., 2011a. Pan-Svalbard growth rate variability and environmental regulation in the Arctic bivalve Serripes groenlandicus. J. Mar. Syst. 88, 239-251. URL: http://linkinghub.elsevier.com/retrieve/ pii/S0924796311000996, doi:10.1016/j.jmarsys.2011.04.010.

Carroll, M.L., Ambrose Jr, W.G., Levin, B.S., Ryan, S.K., Ratner, A.R., Henkes, G.A., Greenacre, M.J., 2011b. Climatic regulation of Clinocardium ciliatum (Bivalvia) growth in the northwestern Barents Sea. Palaeogeogr. a Palaeoclimatol. Palaeoecol. 302, 10-20. doi:10.1016/j.palaeo.2010.06. 001 .

Carroll, M.L., Ambrose Jr, W.G., Locke V, W.L., Ryan, S.K., Johnson, B.J., 2014. Bivalve growth rate and isotopic variability across the n Barents Sea Polar Front. J. Mar. Syst. 130, 167-180. URL: http: a //linkinghub.elsevier.com/retrieve/pii/S0924796313002121, doi 10 . 1016/j.jmarsys.2013.10.006.

Carroll, M.L., Johnson, B.J., Henkes, G.A., McMahon, K.W., Voronkov, A., Ambrose Jr, W.G., Denisenko, S.G., 2009. Bivalves as indicators of environmental variation and potential anthropogenic impacts in the southern Barents ( Sea. Mar. Pollut. Bull. 59, 193-206. doi:DOI10.1016/j.marpolbul.2009.02. 022 .

Case, D.H., Robinson, L.F., Auro, M.E., Gagnon, A.C., 2010. Environmental and biological controls on $\mathrm{Mg}$ and $\mathrm{Li}$ in deep-sea scleractinian corals. Earth

口 Planet. Sci. Lett. 300, 215-225. URL: http://linkinghub.elsevier.com/ retrieve/pii/S0012821X10006047, doi:10.1016/j.epsl.2010.09.029.

Chauvaud, L., 2005. Shell of the Great Scallop Pecten maximus as a high-frequency archive of paleoenvironmental changes. Geochem. Geo905 phys. Geosyst. 6, 1-15. URL: http://www.agu.org/pubs/crossref/2005/ 2004GC000890.shtml, doi:10.1029/2004GC000890. 
Chauvaud, L., Thouzeau, G., Paulet, Y.M., 1998. Effects of environmental factors on the daily growth rate of Pecten maximus juveniles in the Bay of Brest (France). J. Exp. Mar. Bio. Ecol. 227,

83-111. URL: http://www.sciencedirect.com/science/article/pii/ S0022098197002633, doi 10.1016/S0022-0981(97)00263-3.

Checa, A., 2000. A new model for periostracum and shell formation in Unionidae

q (Bivalvia, Mollusca). Tissue \& Cell 32, 405-416. URL: http://www.ncbi. nlm.nih.gov/pubmed/11201280, doi:10.1054/tice.2000.0129

915 Clapham, M.E., Bottjer, D.J., 2007. Permian marine paleoecology and its implications for large-scale decoupling of brachiopod and bivalve abundance and diversity during the Lopingian (Late Permian). Palaeogeogr. Palaeocli口 matol. Palaeoecol. 249, 283-301. URL: http://linkinghub.elsevier.com/ retrieve/pii/S0031018207000600, doi:10.1016/j.palaeo.2007.02.003.

920 Corey, D.M., Dunlap, W.P., Burke, M.J., 1998. Averaging correlations: expected values and bias in combined Pearson $\mathrm{r}$ s and Fisher's z transforma-

n tions. J. Gen. Psychol. 125, 245-261. URL: http://dx.doi.org/10.1080/ 00221309809595548 , doi $10.1080 / 00221309809595548$

Dame, R.F., 2012. Introduction, in: Ecology of Marine Bivalves, An Ecosystem Approach. CRC Press, Boca Raton, FL, USA, pp. 1-19.

Dehairs, F., Baeyens, W., Van Gansbeke, D., 1989. Tight coupling between enrichment of iron and manganese in North Sea suspended matter and sedimentary redox processes: Evidence for seasonal variability. Estuar. Coast.

q Shelf Sci. 29, 457-471. URL: http://dx.doi.org/10.1016/0272-7714(89) 90080-2, doi $10.1016 / 0272-7714$ (89)90080-2.

Dodd, J., 1965. Environmental control of strontium and magnesium in 口 Mytilus. Geochim. Cosmochim. Acta 29, 385-398. URL: http://www. sciencedirect.com/science/article/pii/0016703765900359. 
Elliot, M., Welsh, K., Chilcott, C., McCulloch, M., Chappell, J., Ayling, B., 2009. Profiles of trace elements and stable isotopes derived from giant longlived Tridacna gigas bivalves: Potential applications in paleoclimate stud-

n ies. Palaeogeogr. Palaeoclimatol. Palaeoecol. 280, 132-142. URL: http:

a //linkinghub.elsevier.com/retrieve/pii/S003101820900220X, doi 10. $1016 / \mathrm{j}$.palaeo.2009.06.007

940 Fisher, N.S., Guillard, R.R.L., Bankston, D.C., 1991. The accumulation of barium by marine phytoplankton grown in culture. J. Mar.

(1) Res. 49, 339-354. URL: http://openurl.ingenta.com/content/xref?

a genre=article\&issn=0022-2402\&volume=49\&issue=2\&spage=339, doi 10 . $1357 / 002224091784995882$.

945 Fisher, R.A., 1921. On the "Probable Error" of a Coefficient of Correlation deduced from a Small Sample. Metron 1, 3-32.

Freitas, P., Clarke, L.J., Kennedy, H., Richardson, C.A., Abrantes, F., 2005. $\mathrm{Mg} / \mathrm{Ca}, \mathrm{Sr} / \mathrm{Ca}$, and stable-isotope $\left(\delta^{18} \mathrm{O}\right.$ and $\left.\delta^{13} \mathrm{C}\right)$ ratio profiles from the fan mussel Pinna nobilis: Seasonal records and temperature relationships.

950 Geochem. Geophys. Geosyst. 6, 1-16. URL: http://www.agu.org/pubs/ crossref/2005/2004GC000872.shtml, doi:10.1029/2004GC000872.

Freitas, P.S., Clarke, L.J., Kennedy, H., Richardson, C.A., 2012. The potential of combined $\mathrm{Mg} / \mathrm{Ca}$ and $\delta^{18} \mathrm{O}$ measurements within the shell of the bivalve Pecten maximus to estimate seawater $\delta^{18} \mathrm{O}$ composition. Chem.

955 Geol. 291, 286-293. URL: http://linkinghub.elsevier.com/retrieve/ pii/S0009254111004323, doi:10.1016/j.chemgeo.2011.10.023.

Freitas, P.S., Clarke, L.J., Kennedy, H., Richardson, C.A., Abrantes, F., 2006. Environmental and biological controls on elemental $(\mathrm{Mg} / \mathrm{Ca}, \quad \mathrm{Sr} / \mathrm{Ca}$ and $\mathrm{Mn} / \mathrm{Ca})$ ratios in shells of the king scallop ${ }_{960}$ Pecten maximus. Geochim. Cosmochim. Acta 70, 5119-5133. URL: 1. http://wWw.sciencedirect.com/science/article/B6V66-4KSSWGJ-4/2/ 249c143a6ed425a6488f1c8cc7e9771c. 
Freitas, P.S., Clarke, L.J., Kennedy, H.A., Richardson, C.A., 2008. Inter- and intra-specimen variability masks reliable temperature control on shell $\mathrm{Mg} / \mathrm{Ca}$ ratios in laboratory and field cultured Mytilus edulis and Pecten maximus

a (Bivalvia). Biogeosciences 5, 1245-1258. URL: http://hdl.handle.net/ $10242 / 38468$.

Freitas, P.S., Clarke, L.J., Kennedy, H.A., Richardson, C.A., 2009. Ion microprobe assessment of the heterogeneity of $\mathrm{Mg} / \mathrm{Ca}, \mathrm{Sr} / \mathrm{Ca}$ and $\mathrm{Mn} / \mathrm{Ca}$ ratios in Pecten maximus and Mytilus edulis (Bivalvia) shell calcite precipitated at constant temperature. Biogeosciences 6, 12091227. URL: http://www.biogeosciences.net/6/1209/2009/http://hdl. handle.net/10242/44706, doi $10.5194 / \mathrm{bg}-6-1209-2009$.

Füllenbach, C.S., Schöne, B.R., Mertz-Kraus, R., 2015. Strontium/lithium ratio in aragonitic shells of Cerastoderma edule (Bivalvia) - A new potential temperature proxy for brackish environments. Chem. Geol. 417, 341355. URL: http://dx.doi.org/10.1016/j.chemgeo.2015.10.030, doi 10 . $1016 / j$. chemgeo.2015.10.030.

Gabitov, R.I., Schmitt, A.K., Rosner, M., McKeegan, K.D., Gaetani, G.A., ${ }_{980}$ Cohen, A.L., Watson, E.B., Harrison, T.M., 2011. In situ $\delta^{7} \mathrm{Li}, \mathrm{Li} / \mathrm{Ca}$, and $\mathrm{Mg} / \mathrm{Ca}$ analyses of synthetic aragonites. Geochem. Geophys. Geosyst. 12,

a Q03001:1-6. URL: 〈GotoISI>://000288086000001, doi ArtnQ03001Doi10. $1029 / 2010 \mathrm{gc003322}$.

Gaetani, G.A., Cohen, A.L., 2006. Element partitioning during precipitation of aragonite from seawater: A framework for understanding paleoproxies. Geochim. Cosmochim. Acta 70, 4617-4634.

a URL: <GotoISI>://000241001400004http://linkinghub.elsevier.com/ retrieve/pii/S0016703706018783, doi:DOI10.1016/j.gca.2006.07.008.

Genizi, A., 1993. Decomposition of $\mathrm{R}^{2}$ in multiple regression with correlated regressors. Stat. Sin. 3, 407-420. 
Gillikin, D., Dehairs, F., Lorrain, A., Steenmans, D., Baeyens, W., Andre, L., 2006. Barium uptake into the shells of the common mussel (Mytilus edulis) and the potential for estuarine paleo-chemistry reconstruction. Geochim. Cosmochim. Acta 70, 395-407. URL: http://linkinghub.elsevier.com/ retrieve/pii/S0016703705007830, doi:10.1016/j.gca.2005.09.015

Gillikin, D.P., Lorrain, A., Navez, J., Taylor, J.W., André, L., Keppens, E., Baeyens, W., Dehairs, F., 2005. Strong biological controls on Sr/Ca ratios in aragonitic marine bivalve shells. Geochem. Geophys. Geosyst. 6, 1-16. doi:10.1029/2004gc000874.

Gillikin, D.P., Lorrain, A., Paulet, Y.m., André, L., Dehairs, F., 2008. Synchronous barium peaks in high-resolution profiles of calcite and aragonite marine bivalve shells. Geo-Marine Lett. 28, 351-358. URL: http://www.springerlink.com/index/10.1007/s00367-008-0111-9, doi:10.1007/s00367-008-0111-9.

1005 Goodwin, D., Flessa, K., Tellezduarte, M., Dettman, D., Schöne, B.R., Avilaserrano, G., 2004. Detecting time-averaging and spatial mixing using oxygen isotope variation: a case study. Palaeogeogr. Palaeoclimatol. Palaeoecol. 205, 1-21. URL: http://linkinghub.elsevier.com/retrieve/ pii/S0031018203007521 doi $10.1016 / j \cdot$ palaeo.2003.10.020

Goodwin, D.H., Gillikin, D.P., Roopnarine, P.D., 2013. Preliminary evaluation of potential stable isotope and trace element productivity proxies in the oyster Crassostrea gigas. Palaeogeogr. Palaeoclimatol. Palaeoecol. 373, 88-97. URL: http://dx.doi.org/10.1016/j.palaeo.2012.03.034, doi $10.1016 / \mathrm{j} \cdot \mathrm{palaeo} \cdot 2012.03 .034$.

Grömping, U., 2006. Relative Importance for Linear Regression in R: The 口 Package relaimpo. J. Stat. Softw. 17, 1-27. URL: http://www .jstatsoft. org/v17/i01.

Hathorne, E.C., Felis, T., Suzuki, A., Kawahata, H., Cabioch, G., 2013. Lithium in the aragonite skeletons of massive Porites corals: A new tool 
口 152. URL: http://doi.wiley.com/10.1029/2012PA002311, doi 10.1029/ 2012PA002311.

Henkes, G.A., Passey, B.H., Wanamaker, A.D., Grossman, E.L., Ambrose Jr, W.G., Carroll, M.L., 2013. Carbonate clumped isotope compositions of modern marine mollusk and brachiopod shells. Geochim. Cosmochim. 口 Acta 106, 307-325. URL: http://linkinghub.elsevier.com/retrieve/ pii/S0016703712007399, doi $10.1016 / j \cdot g c a .2012 .12 .020$.

Howe, J.A., Harland, R., Cottier, F.R., Brand, T., Willis, K.J., Berge, J., Grosfjeld, K., Eriksson, A., 2010. Dinoflagellate cysts as proxies for palaeoceanographic conditions in Arctic fjords. Geol. Soc. Spec. Publ. 344, 61-

74. URL: http://sp.lyellcollection.org/cgi/doi/10.1144/SP344.6, doi $10.1144 /$ SP344.6.

Johnson, P.C., 2014. Extension of Nakagawa \& Schielzeth's R ${ }^{2}{ }_{G L M M}$ to random 口 slopes models. Methods Ecol. Evol. 5, 944-946. URL: http://doi.wiley. com/10.1111/2041-210X.12225, doi:10.1111/2041-210X.12225.

Jones, D.S., 1980. Annual cycle of shell growth increment formation in two continental shelf bivalves and its paleoecologic significance. Paleobiol-

口 ogy 6, 331-340. URL: http://www.journals.cambridge.org/abstract_ S0094837300006837, doi $10.1017 /$ S0094837300006837

Khim, B.K., Krantz, D.E., Cooper, L.W., Grebmeier, J.M., 2003. Seasonal discharge of estuarine freshwater to the western Chukchi Sea shelf identified in stable isotope profiles of mollusk shells. J. Geophys. Res. 108, 1-10. URL: http://dx.doi.org/10.1029/2003JC001816, doi10.1029/2003JC001816.

Klein, R.T., Lohmann, K.C., Kennedy, G.L., 1997. Elemental and isotopic 1045 proxies of paleotemperature and paleosalinity: Climate reconstruction of the marginal northeast Pacific ca. 80 ka. Geology 25, 363. URL:

a http://geology.gsapubs.org/cgi/doi/10.1130/0091-7613(1997) 
025<0363:EAIPOP>2.3.C0;2 doi 10.1130/0091-7613(1997)025<0363:

EAIPOP>2.3. CO;2.

1050

\section{6/0031-0182(87)90064-2.}

Lazareth, C., Le Cornec, F., Candaudap, F., Freydier, R., 2013. Trace element heterogeneity along isochronous growth layers in bivalve shell:

1060 Consequences for environmental reconstruction. Palaeogeogr. Palaeocli-

\ matol. Palaeoecol. 373, 39-49. URL: http://linkinghub.elsevier.com/ retrieve/pii/S0031018211002264, doi:10.1016/j.palaeo.2011.04.024.

Lazareth, C., Putten, E., André, L., Dehairs, F., 2003. High-resolution trace element profiles in shells of the mangrove bivalve Isognomon ephippium: a record of environmental spatio-temporal variations? Estuar. Coast. Shelf Sci.

[ 57, 1103-1114. URL: http://linkinghub.elsevier.com/retrieve/pii/ S0272771403000131, doi 10.1016/S0272-7714(03)00013-1.

Lindeman, R., Merenda, P., Gold, R., 1980. Introduction to Bivariate and Multivariate Analysis. Scott Foresman \& Co, Glenview, IL, USA.

Lorens, R., 1981. Sr, Cd, Mn and Co distribution coefficients in calcite as a function of calcite precipitation rate. Geochim. Cosmochim. Acta 45,

1 553-561. URL: http://www.sciencedirect.com/science/article/pii/ 0016703781901885 .

Lorens, R., Bender, M., 1980. The impact of solution chemistry on Mytilus edulis 
calcite and aragonite. Geochim. Cosmochim. Acta 44, 1265-1278. URL: http: //www.sciencedirect.com/science/article/pii/0016703780900873.

Lorrain, A., Gillikin, D.P., Paulet, Y.M., Chauvaud, L., Mercier, A.L., Navez, J., André, L., 2005. Strong kinetic effects on $\mathrm{Sr} / \mathrm{Ca}$ ratios in the calcitic bivalve org/cgi/doi/10.1130/G22048.1, doi:10.1130/G22048.1.

Lorrain, A., Paulet, Y.M., Chauvaud, L., Dunbar, R., Mucciarone, D., Fontugne, M., 2004. $\delta^{13} \mathrm{C}$ variation in scallop shells: Increasing metabolic carbon contribution with body size? Geochim. Cosmochim. Acta 68,

a 3509-3519. URL: http://www.sciencedirect.com/science/article/pii/ $1085 \quad$ S0016703704001243, doi $10.1016 / \mathrm{j}$. gca.2004.01.025

Marali, S., Schöne, B.R., Mertz-Kraus, R., Griffin, S.M., Wanamaker, A.D., Matras, U., Butler, P.G., 2015. Ba/Ca ratios in shells of Arctica islandicaPotential environmental proxy and crossdating tool. Palaeogeogr. Palaeoclimatol. Palaeoecol. URL: http://linkinghub.elsevier.com/retrieve/ pii/S0031018215007440, doi 10.1016/j.palaeo.2015.12.018

Marin, F., 2012. The formation and mineralization of mollusk shell. \ Front. Biosci. S4, 1099-1125. URL: http://europepmc.org/abstract/med/ 22202112, doi $10.2741 /$ S321.

Masson-Delmotte, V., Schulz, M., Abe-Ouchi, A., Beer, J., Ganopolski, A., Rouco, J.G., Jansen, E., Lambeck, K., Luterbacher, J., Naish, T., Osborn, T., Otto-Bliesner, B., Quinn, T., Ramesh, R., Rojas, M., Shao, X., Timmermann, A., 2013. Information from paleoclimate archives, in: Stocker, T., Qin, D., Plattner, G.K., Tignor, M., Allen, S., Boschung, J., Nauels, A., Xia, Y., Bex, V., Midgley, P. (Eds.), Climate Change 2013: The Physical Science 1100 Basis. Contribution of Working Group I to the Fifth Assessment Report of the Intergovernmental Panel on Climate Change. Cambridge University Press, Cambridge, UK and New York, NY, USA. chapter 5, pp. 383-464. URL: http://www.ipcc.ch/report/ar5/wg1/ 
McCullagh, P., Nelder, J.A., 1989. Generalized linear models. volume 37. 2nd ed., CRC press, Boca Raton, FL, USA.

Mokgalaka, N.S., Gardea-Torresdey, J.L., 2006. Laser ablation inductively coupled plasma mass spectrometry: principles and applications. Appl. Spectrosc.

¿ Rev. 41, 131-150. URL: http://www.tandfonline.com/doi/abs/10.1080/ 05704920500510703 , doi $10.1080 / 05704920500510703$.

Norwegian Meteorological Institute, 2014. Icechart archive. Polar View - European Arctic node. URL: http://polarview.met.no.

Oomori, T., Kaneshima, H., Maezato, Y., Kitano, Y., 1987. Distribution coefficient of $\mathrm{Mg}^{2+}$ ions between calcite and solution at $10-50^{\circ} \mathrm{C}$. Mar. Chem. 20,

\327-336. URL: http://wWW.sciencedirect.com/science/article/pii/ 0304420387900661 .

Pearce, N.J.G., Mann, V.L., 2006. Trace metal variations in the shells of Ensis siliqua record pollution and environmental conditions in the sea to the west

¿ of mainland Britain. Mar. Pollut. Bull. 52, 739-55. URL: http://www.ncbi. nlm.nih.gov/pubmed/16375930, doi:10.1016/j.marpolbul.2005.11.003.

1120 Pearson, K., 1901. On lines and planes of closest fit to systems of points

口 in space. Philos. Mag. 2, 559-572. URL: http://dx.doi.org/10.1080/

1. 14786440109462720http://www.tandfonline.com/doi/abs/10.1080/ 14786440109462720 , doi $10.1080 / 14786440109462720$.

Pearson, P.N., Palmer, M.R., 2000. Atmospheric carbon dioxide concentrations 1125 over the past 60 million years. Nature 406, 695-699. URL: http://www. ncbi.nlm.nih.gov/pubmed/10963587, doi:10.1038/35021000,

Pinheiro, J., Bates, D., 2014. nlme: Linear and Nonlinear Mixed Effects Models. URL: http://cran.r-project.org/package=nlme.

Poulain, C., Gillikin, D.P., Thébault, J., Munaron, J.M., Bohn, M., Robert, R., Paulet, Y.M., Lorrain, a., 2015. An evaluation of $\mathrm{Mg} / \mathrm{Ca}$, Sr/Ca 
, and $\mathrm{Ba} / \mathrm{Ca}$ ratios as environmental proxies in aragonite bivalve shells. Chem. Geol. URL: http://dx.doi.org/10.1016/j.chemgeo.2014.12.019, doi:10.1016/j.chemgeo.2014.12.019

Purton, L.M.A., Shields, G., Brasier, M., Sciences, E., Road, P., Ox, O., 1999. Metabolism controls $\mathrm{Sr} / \mathrm{Ca}$ ratios in fossil aragonitic mollusks. Geology 27, 1083-1086. URL: http://geology.gsapubs .org/content/27/12/ 1083.short, doi $10.1130 / 0091-7613(1999) 027<1083$.

R Core Team, 2016. R: A language and environment for statistical computing.

q R Foundation for Statistical Computing, Vienna, Austria. URL: http:// wWw.r-project.org.

Richardson, C., 2004. Age, growth rate and season of recruitment of Pinna nobilis (L) in the Croatian Adriatic determined from Mg:Ca and Sr:Ca shell

口 profiles. J. Exp. Mar. Bio. Ecol. 299, 1-16. doi 10.1016/j.jembe.2003.08. 012 .

Richardson, C.A., 2001. Molluscs as archives of environmental change. Oceanogr. Mar. Biol. an Annu. Rev. 39, 103-164.

Rollion-Bard, C., Blamart, D., 2015. Possible controls on Li, Na, and $\mathrm{Mg}$ incorporation into aragonite coral skeletons. Chem. Geol. 396, 98-

a 111. URL: http://dx.doi.org/10.1016/j.chemgeo.2014.12.011, doi 10 . 1016/j.chemgeo.2014.12.011.

Saenger, C., Cohen, A.L., Oppo, D.W., Hubbard, D., 2008. Interpreting sea surface temperature from strontium/calcium ratios in Montastrea corals: Link with growth rate and implications for proxy reconstructions. Paleoceanog-

a raphy 23, PA3102:1-11. URL: http://www.agu.org/pubs/crossref/2008/ 2007PA001572.shtm1, doi:10.1029/2007PA001572.

Schneider, C.A., Rasband, W.S., Eliceiri, K.W., 2012. NIH Image to ImageJ:

口 25 years of image analysis. Nat. Methods 9, 671-675. URL: http://www. nature.com/doifinder/10.1038/nmeth.2089, doi 10.1038/nmeth.2089. 
Schneider, J.A., Carter, J.G., 2001. Evolution and phylogenetic significance of cardioidean shell microstructure (Mollusca, Bivalvia). J. Paleontol. 75, 607-643. URL: http://www.jstor.org/stable/1307048.

Schöne, B.R., 2008. The curse of physiology - challenges and opportunities in the interpretation of geochemical data from mollusk shells. Geo-Marine Lett. 28, 269-285. URL: http://link.springer.com/10.1007/s00367-008-0114-6, doi:10.1007/s00367-008-0114-6.

Schöne, B.R., Houk, S.D., Freyre Castro, A.D., Fiebig, J., Oschmann, W., Kröncke, I., Dreyer, W., Gosselck, F., 2005a. Daily growth rates in shells of Arctica islandica: Assessing sub-seasonal environmental cona trols on a long-lived bivalve mollusk. Palaios 20, 78-92. URL: http:// 1170 palaios.sepmonline.org/cgi/doi/10.2110/palo.2003.p03-101 doi 10 . 2110/palo.2003.p03-101

Schöne, B.R., Pfeiffer, M., Pohlmann, T., Siegismund, F., 2005b. A seasonally resolved bottom-water temperature record for the period AD 1866-2002 based on shells of Arctica islandica (Mollusca, North Sea). Int. J. Climatol. 25, 947-

1175 962. URL: http://doi.wiley.com/10.1002/joc.1174, doi:10.1002/joc. 1174

Schöne, B.R., Radermacher, P., Zhang, Z., Jacob, D.E., 2013. Crystal fabrics and element impurities $(\mathrm{Sr} / \mathrm{Ca}, \mathrm{Mg} / \mathrm{Ca}$, and $\mathrm{Ba} / \mathrm{Ca}$ ) in shells of Arctica islandica - Implications for paleoclimate reconstructions. Palaeogeogr. Palaeoclimatol. Palaeoecol. 373, 50-59. URL: http://www.sciencedirect.com/ a science/article/pii/S0031018211002586, doi 10.1016/j.palaeo.2011. 05.013 .

Schöne, B.R., Zhang, Z., Jacob, D., Gillikin, D.P., Tutken, T., Garbe-Schonberg, D., McConnaughey, T., Soldati, A., 2010. Effect of organic matrices on the 1185 determination of the trace element chemistry $(\mathrm{Mg}, \mathrm{Sr}, \mathrm{Mg} / \mathrm{Ca}, \mathrm{Sr} / \mathrm{Ca})$ of aragonitic bivalve shells (Arctica islandica) - Comparison of ICP-OES and LA-ICP-MS data. Geochem. J. 44, 23-37. 
Schöne, B.R., Zhang, Z., Radermacher, P., Thébault, J., Jacob, D.E., Nunn, E.V., Maurer, A.F., 2011. Sr/Ca and Mg/Ca ratios of ontoge-

Sejr, M.K., Blicher, M.E., Rysgaard, S., 2009. Sea ice cover affects inter-annual and geographic variation in growth of the Arctic cockle Clinocardium ciliatum (Bivalvia) in Greenland. Mar. Ecol. Ser. 389, 149158. URL: http://www.int-res.com/abstracts/meps/v389/p149-158/, doi:Doi10.3354/Meps08200.

Selin, N.I., 2010. The growth and life span of bivalve mollusks at the northeastern coast of Sakhalin Island. Russ. J. Mar. Biol. 36, 258-269. doi:10.1134/s1063074010040048.

Shirai, K., Schöne, B.R., Miyaji, T., Radarmacher, P., Krause, R.A., Tanabe, K., 2014. Assessment of the mechanism of elemental incorporation into bivalve shells (Arctica islandica) based on elemental distribution at the min crostructural scale. Geochim. Cosmochim. Acta 126, 307-320. URL: http:

[ //linkinghub.elsevier.com/retrieve/pii/S0016703713006224, doi 10 . $1016 / j \cdot g c a .2013 .10 .050$.

Shirai, K., Takahata, N., Yamamoto, H., Omata, T., Sasaki, T., Sano, Y., 2008. Novel analytical approach to bivalve shell biogeochemistry: ${ }_{1210}$ A case study of hydrothermal mussel shell. Geochem. J. 42, 413-

口 420. URL: http://joi.jlc.jst.go.jp/JST.JSTAGE/geochemj/42.413? from=CrossRef, doi $10.2343 /$ geochemj .42 .413 .

Snijders, T.A., Bosker, R.J., 1994. Modeled Variance in Two-Level Models. So口 ciol. Methods Res. 22, 342-363. URL: http://smr.sagepub.com/content/ $1215 \quad 22 / 3 / 342$.abstract, doi $10.1177 / 0049124194022003004$. 
Soldati, A.L., Jacob, D.E., Glatzel, P., Swarbrick, J.C., Geck, J., 2016. Element substitution by living organisms: the case of manganese in mollusc shell aragonite. Sci. Rep. 6, 22514. URL: http://www.nature.com/articles/ srep22514, doi $10.1038 /$ srep22514.

Søreide, J.E., Leu, E., Berge, J., Graeve, M., Falk-Petersen, S., 2010. Timing of blooms, algal food quality and Calanus glacialis reproduction and growth in a changing Arctic. Glob. Chang. Biol. 16, 31543163. URL: http://doi.wiley.com/10.1111/j.1365-2486.2010.02175.x doi: $10.1111 / j .1365-2486.2010 .02175 . x$.

1225 Stanley, S.M., Hardie, L.A., 1998. Secular oscillations in the carbonate mineralogy of reef-building and sediment-producing organisms driven by tectonically forced shifts in seawater chemistry. Palaeogeogr. Palaeoclimatol. Palaeoecol. 144, 3-19. URL: http://dx.doi.org/10.1016/S0031-0182(98)00109-6, doi $10.1016 /$ S0031-0182(98)00109-6.

1230 Stecher, H.A.I., Krantz, D.E., Lord, C.J.I., Luther, G.W.I., Bock, K.W., 1996. Profiles of strontium and barium in Mercenaria mercenaria and Spisula solidissima shells. Geochim. Cosmochim. Acta 60,

1 3445-3456. URL: http://www.sciencedirect.com/science/article/pii/ 0016703796001792, doi $10.1016 / 0016-7037$ (96)00179-2

Strom, A., Francis, R.C., Mantua, N.J., Miles, E.L., Peterson, D.L., 2004. North Pacific climate recorded in growth rings of geoduck clams: A new tool for pale„ oenvironmental reconstruction. Geophys. Res. Lett. 31, L06206. URL: http: //doi.wiley.com/10.1029/2004GL019440, doi:10.1029/2004GL019440.

Sturgeon, R.E., Willie, S.N., Yang, L., Greenberg, R., Spatz, R.O., Chen, Z., 1240 Scriver, C., Clancy, V., Lam, J.W., Thorrold, S., 2005. Certification of a fish otolith reference material in support of quality assurance for trace element a analysis. J. Anal. At. Spectrom. 20, 1067-1071. URL: http://xlink.rsc. org/?DOI=b503655k, doi $10.1039 / \mathrm{b} 503655 \mathrm{k}$. 
Svendsen, H., Beszczynska-Møller, A., Hagen, J.O., Lefauconnier, B., Tverberg,

口

Takesue, R., Bacon, C., Thompson, J., 2008. Influences of organic matter and calcification rate on trace elements in aragonitic estuarine bi-

Takesue, R.K., van Geen, A., 2004. Mg/Ca, Sr/Ca, and stable isotopes in modern and Holocene Protothaca staminea shells from a northern California coastal upwelling region. Geochim. Cosmochim. Acta 68, 3845-3861. URL: http://linkinghub.elsevier.com/retrieve/pii/ S0016703704002467, doi 10.1016/j.gca.2004.03.021.

Thébault, J., Chauvaud, L., 2013. Li/Ca enrichments in great scallop shells (Pecten maximus) and their relationship with phytoplankton blooms. Palaeo- 
\ geogr. Palaeoclimatol. Palaeoecol. 373, 108-122. URL: http://dx.doi.org/ 10.1016/j.palaeo.2011.12.014 doi $10.1016 / j \cdot p a l a e o .2011 .12 .014$.

${ }_{1275}$ Thébault, J., Chauvaud, L., L'Helguen, S., Clavier, J., Barats, A., Jacquet, S., Pecheyran, C., Amouroux, D., 2009a. Barium and molybdenum records in bivalve shells: Geochemical proxies for phytoplankton dynamics in coastal

घ environments? Limnol. Oceanogr. 54, 1002-1014. URL: <GotoISI>: //000268325000031.

Thébault, J., Schöne, B.R., Hallmann, N., Barth, M., Nunn, E.V., 2009b. Investigation of $\mathrm{Li} / \mathrm{Ca}$ variations in aragonitic shells of the ocean quahog Arctica islandica, northeast Iceland. Geochem. Geophys. Geosyst. 10, 1-15. URL: http://dx.doi .org/10.1029/2009GC002789, doi:10.1029/2009gc002789.

Toland, H., Perkins, B., Pearce, N.J.G., Keenan, F., Leng, M.J., 2000. A 1285 study of sclerochronology by laser ablation ICP-MS. J. Anal. At. Spectrom. ¿ 15, 1143-1148. URL: http://xlink.rsc.org/?DOI=b0020141, doi 10.1039/ b0020141.

Torres, M., Barry, J., Hubbard, D., 2001. Reconstructing the history of fluid flow at cold seep sites from $\mathrm{Ba} / \mathrm{Ca}$ ratios in vesicomyid clam shells. Limnol.

1290 ¿ Oceanogr. 46, 1701-1708. URL: http://www.jstor.org/stable/10.2307/ 3069094.

Tribovillard, N., Algeo, T.J., Lyons, T., Riboulleau, A., 2006. Trace metals as paleoredox and paleoproductivity proxies: An update. Chem. Geol. 232, 12-32. doi:DOI10.1016/j.chemgeo.2006.02.012.

Ullmann, C.V., Böhm, F., Rickaby, R.E., Wiechert, U., Korte, C., 2013. The Giant Pacific Oyster (Crassostrea gigas) as a modern analog for fossil ostreoids: Isotopic (Ca, O, C) and elemental $(\mathrm{Mg} / \mathrm{Ca}, \mathrm{Sr} / \mathrm{Ca}, \mathrm{Mn} / \mathrm{Ca})$ proxies.

₫ Geochem. Geophys. Geosyst. 14, 4109-4120. URL: http://doi.wiley.com/ 10.1002/ggge.20257, doi:10.1002/ggge.20257 
1300 Valentine, J.W., Jablonski, D., Kidwell, S., Roy, K., 2006. Assessing the fidelity of the fossil record by using marine bivalves.

¿ Proc. Natl. Acad. Sci. U. S. A. 103, 6599-6604. URL: http:

1] //www.pubmedcentral.nih.gov/articlerender.fcgi?artid=1458929\& tool=pmcentrez\&rendertype=abstract, doi $10.1073 /$ pnas .0601264103 .

Vander Putten, E., Dehairs, F., André, L., Baeyens, W., 1999. Quantitative in situ microanalysis of minor and trace elements in biogenic calcite using infrared laser ablation inductively coupled plasma mass spectrometry: a critical evaluation. Anal. Chim. Acta 378,

\261-272. URL: http://www.sciencedirect.com/science/article/pii/ 1310 S0003267098006138, doi 10.1016/s0003-2670(98)00613-8.

Vander Putten, E., Dehairs, F., Keppens, E., 2000. High resolution distribution of trace elements in the calcite shell layer of modern Mytilus edulis: Environmental and biological controls. Geochim. Cosmochim. Acta 64, 997-1011. URL: http://www.sciencedirect.com/science/article/pii/ S0016703799003804.

Vihtakari, M., 2014. Bivalves as indicators of environmental perturbations related to climate and ocean acidification. Phd thesis. UiT The Arctic University of Norway. URL: http://hdl.handle.net/10037/7152.

Vihtakari, M., 2016. sclero: Measure Growth Patterns and Align Sampling Spots in Photographs. URL: https://cran.r-project.org/package=sclero.

Vihtakari, M., Renaud, P.E., Clarke, L.J., Whitehouse, M.J., Hop, H., Carroll, M.L., Ambrose, W.G., 2016. Decoding the oxygen isotope signal for seasonal growth patterns in Arctic bivalves. Palaeogeogr. Palaeoclimatol. Palaeoecol. 446, 263-283. URL: http://dx.doi.org/10.1016/j.palaeo.2016.01.008, doi:10.1016/j.palaeo.2016.01.008.

Wallace, M.I., Cottier, F.R., Berge, J., Tarling, G.A., Griffiths, C., Brierley, A.S., 2010. Comparison of zooplankton vertical migration in an ice-free and 
a seasonally ice-covered Arctic fjord: An insight into the influence of sea ice cover on zooplankton behavior. Limnol. Oceanogr. 55, 831-845.

Wanamaker, A.D., Butler, P.G., Scourse, J.D., Heinemeier, J., Eiríksson, J., Knudsen, K.L., Richardson, C.A., 2012. Surface changes in the North Atlantic meridional overturning circulation during the last millennium. Nat. Commun. 3, 1-7. URL: http://www.nature.com/doifinder/10.1038/ncomms1901, doi:10.1038/ncomms 1901 ,

1335 Wanamaker, A.D., Hetzinger, S., Halfar, J., 2011. Reconstructing mid- to high-latitude marine climate and ocean variability using bivalves, coralline algae, and marine sediment cores from the Northern Hemisphere. Palaeogeogr. Palaeoclimatol. Palaeoecol. 302, 1-9. URL: http://linkinghub.elsevier. a com/retrieve/pii/S0031018210007492, doi 10.1016/j.palaeo.2010.12. 024 .

Wanamaker, A.D., Kreutz, K.J., Wilson, T., Borns Jr, H.W., Introne, D.S., Feindel, S., 2008. Experimentally determined $\mathrm{Mg} / \mathrm{Ca}$ and $\mathrm{Sr} / \mathrm{Ca}$ ratios in juvenile bivalve calcite for Mytilus edulis: implications for paleotem-

a perature reconstructions. Geo-Marine Lett. 28, 359-368. doi 10.1007/ s00367-008-0112-8.

Wassmann, P., Duarte, C.M., Agustí, S., Sejr, M.K., 2011. Footprints of climate change in the Arctic marine ecosystem. Glob. Chang. Biol.

(1) 17, 1235-1249. URL: http://onlinelibrary.wiley.com/doi/10.1111/

a j.1365-2486.2010.02311.x/abstract, doi $10.1111 / \mathrm{j} .1365-2486.2010$. $1350 \quad 02311 \cdot \mathrm{x}$

Weiner, S., Dove, P., 2003. An overview of biomineralization processes and the problem of the vital effect. Rev. Mineral. Geochemisty 54, 1-29. URL: http://rimg.geoscienceworld.org/content/54/1/1.short

Wheeler, A.P., 1992. Mechanisms of molluscan shell formation, in: Bonucci, E. 1355 (Ed.), Calcification in Biological Systems. CRC Press, Boca Raton, FL, USA. chapter 9, pp. 179-216. 
Yan, H., Shao, D., Wang, Y., Sun, L., 2013. Sr/Ca profile of long-lived - textitTridacna gigas bivalves from South China Sea: A new high-resolution SST proxy. Geochim. Cosmochim. Acta 112, 5265. URL: http://dx.doi.org/10.1016/j.gca.2013.03.007http://www.

sciencedirect.com/science/article/pii/S001670371300149X doi 10 . $1016 /$ j.gca.2013.03.007

Yoshinaga, J., Nakama, A., Morita, M., Edmonds, J.S., 2000. Fish otolith reference material for quality assurance of chemical analyses. Mar.

1365 Chem. 69, 91-97. URL: http://linkinghub.elsevier.com/retrieve/pii/ S0304420399000985, doi 10.1016/S0304-4203(99) 00098-5.

Zhao, L., Schöne, B.R., Mertz-Kraus, R., 2015. Controls on strontium and barium incorporation into freshwater bivalve shells (Corbicula flun minea). Palaeogeogr. Palaeoclimatol. Palaeoecol. , 1-9URL: http://www. 1370 Sciencedirect.com/science/article/pii/S0031018215007105http:

//linkinghub.elsevier.com/retrieve/pii/S0031018215007105, doi:10.1016/j.palaeo.2015.11.040. 


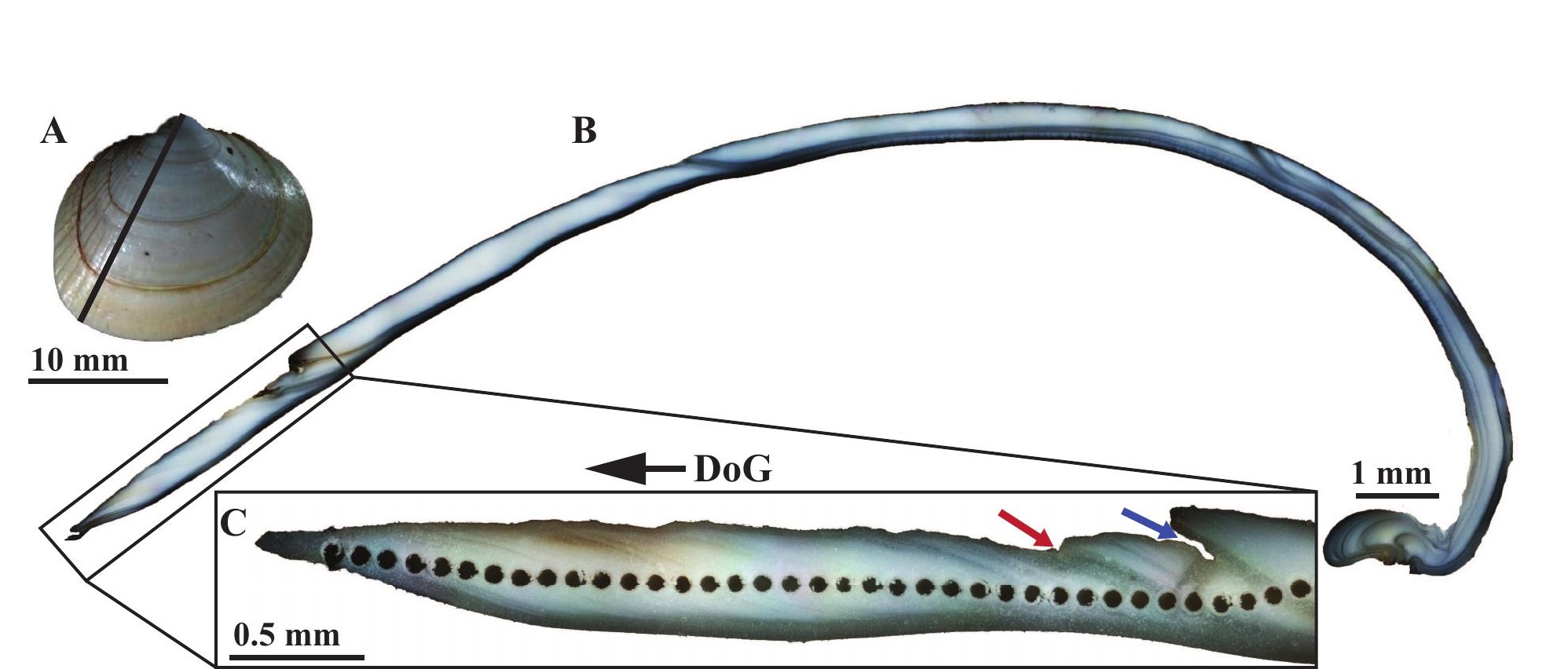

Figure 1

Figure 1

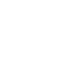


Figure 2

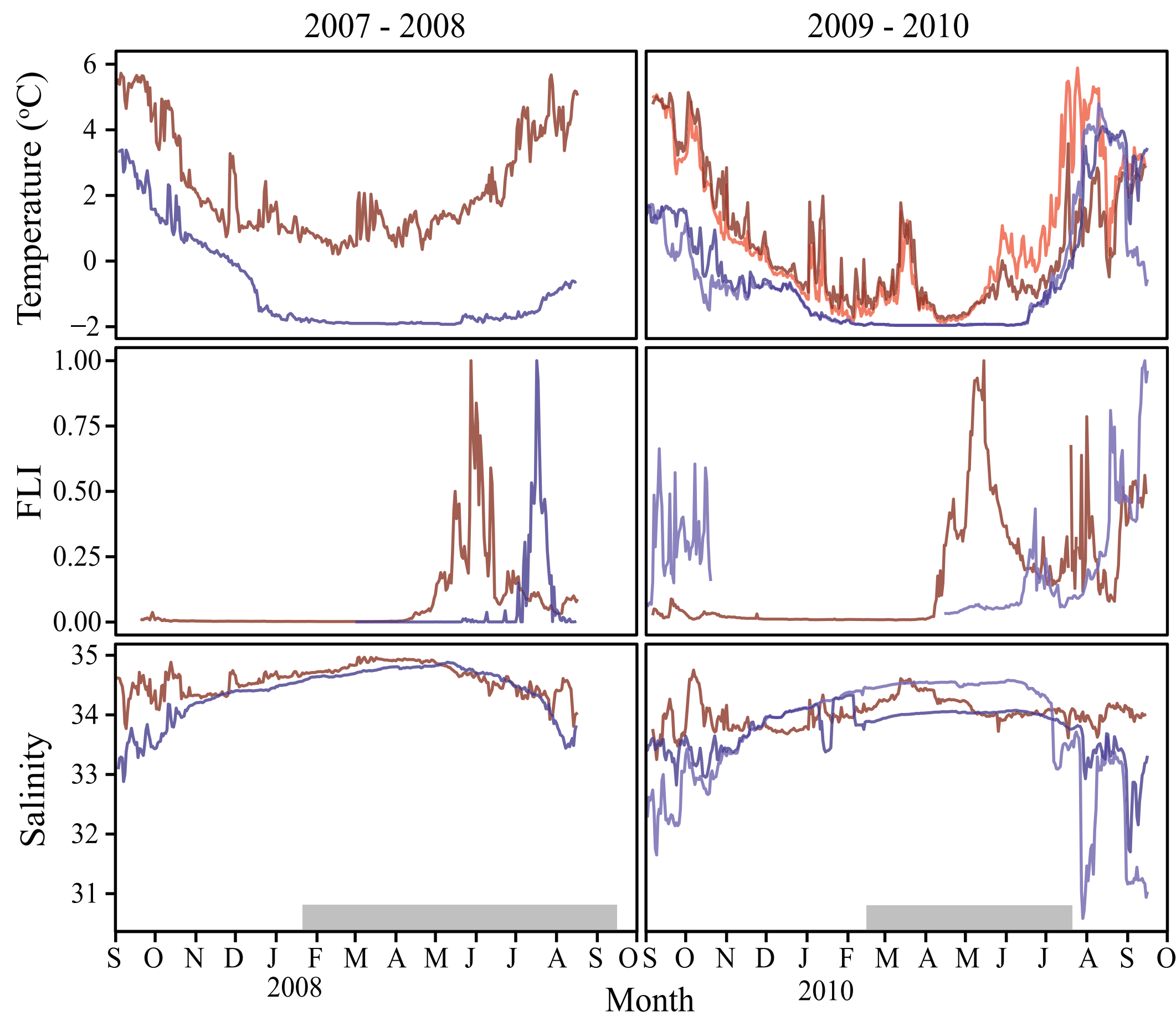


Figure 4

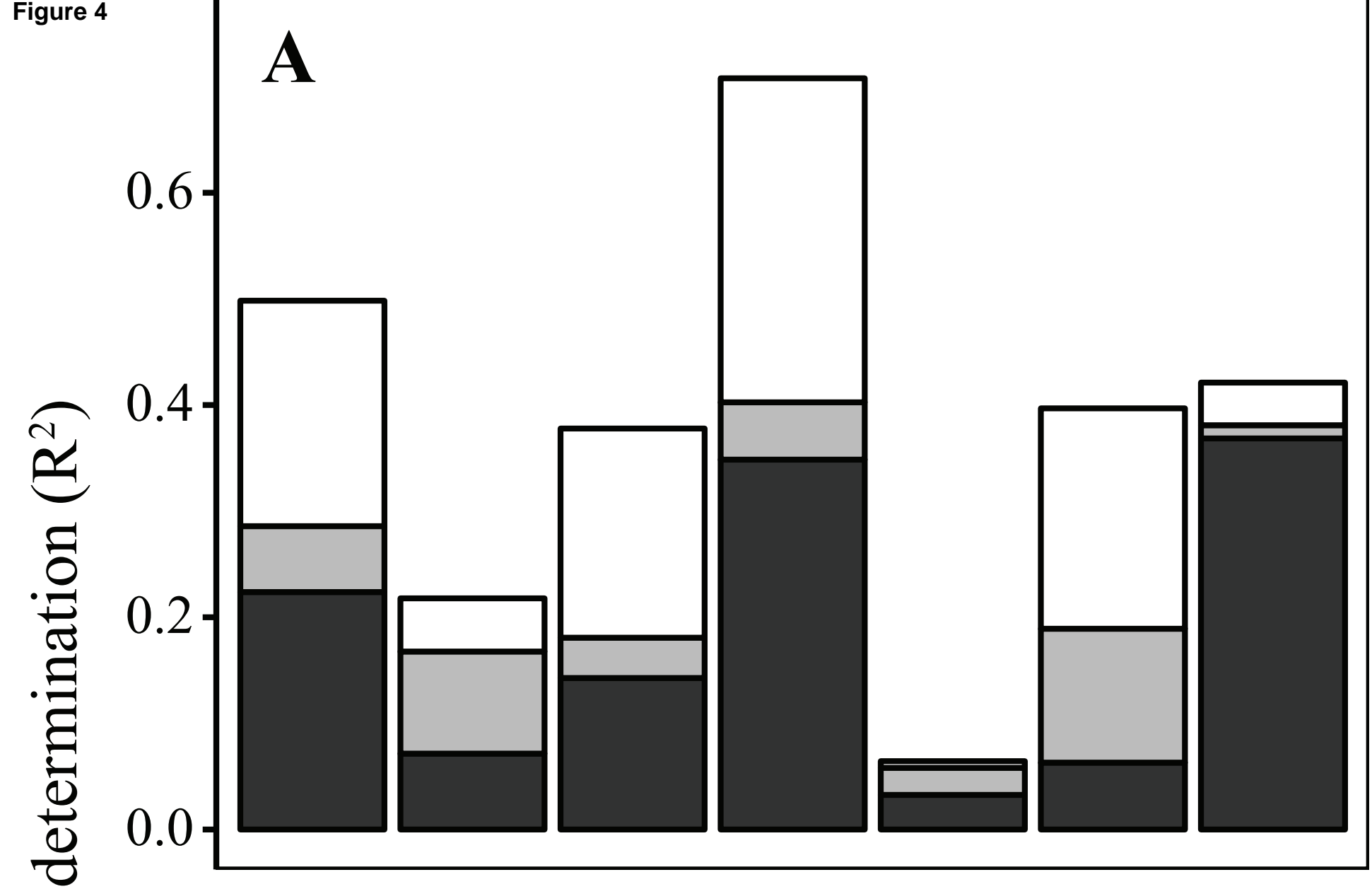

4
0
0
0
0
0
0
0
0
0
0

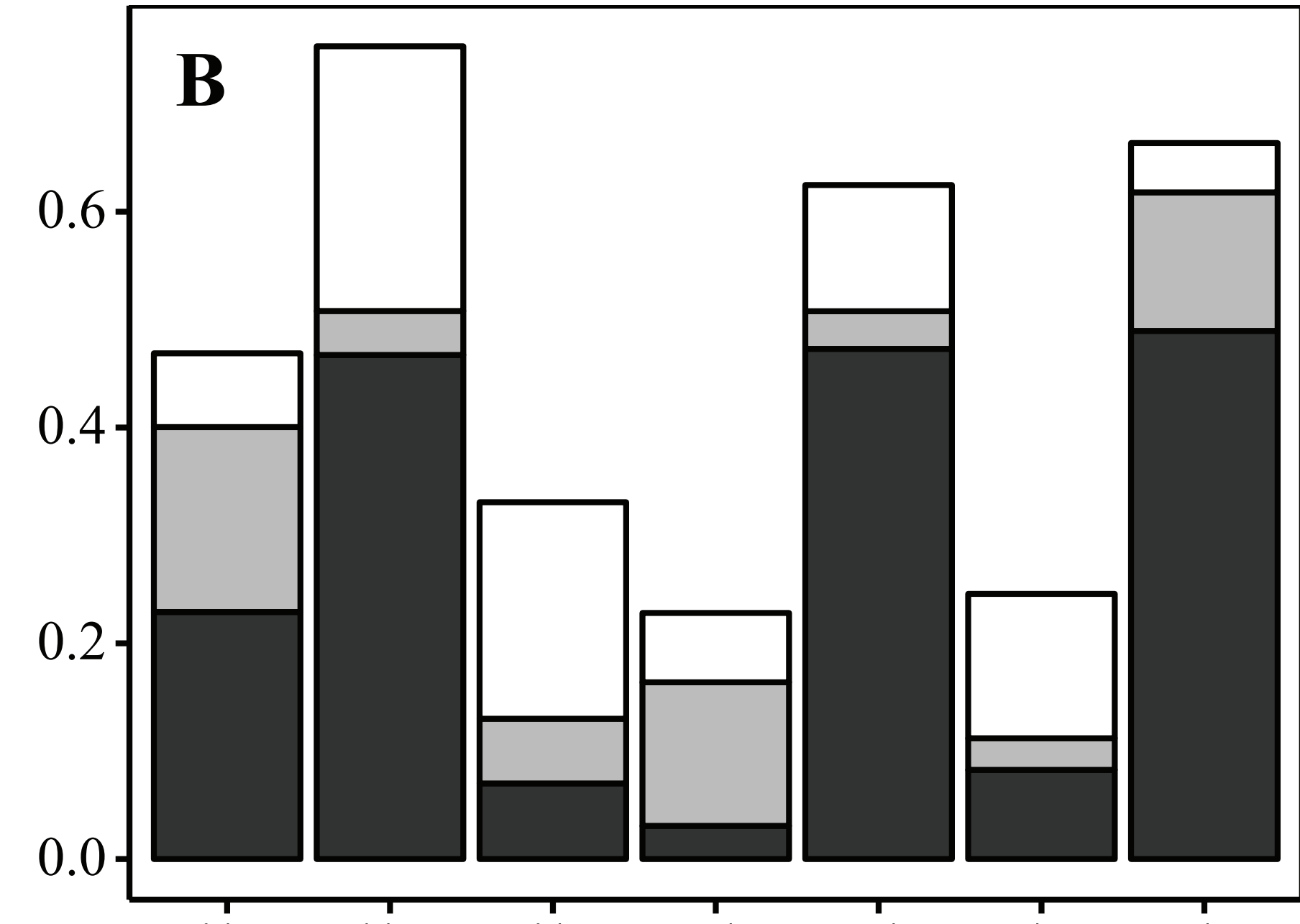

$\mathrm{Li} / \mathrm{Ca} \quad \mathrm{Li} / \mathrm{Mg} \mathrm{Li} / \mathrm{Sr} \mathrm{Mg} / \mathrm{Ca} \mathrm{Mn} / \mathrm{Ca} \mathrm{Sr} / \mathrm{Ca} \mathrm{Ba} / \mathrm{Ca}$ Element ratio 

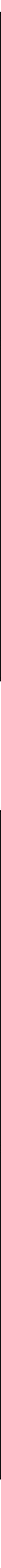


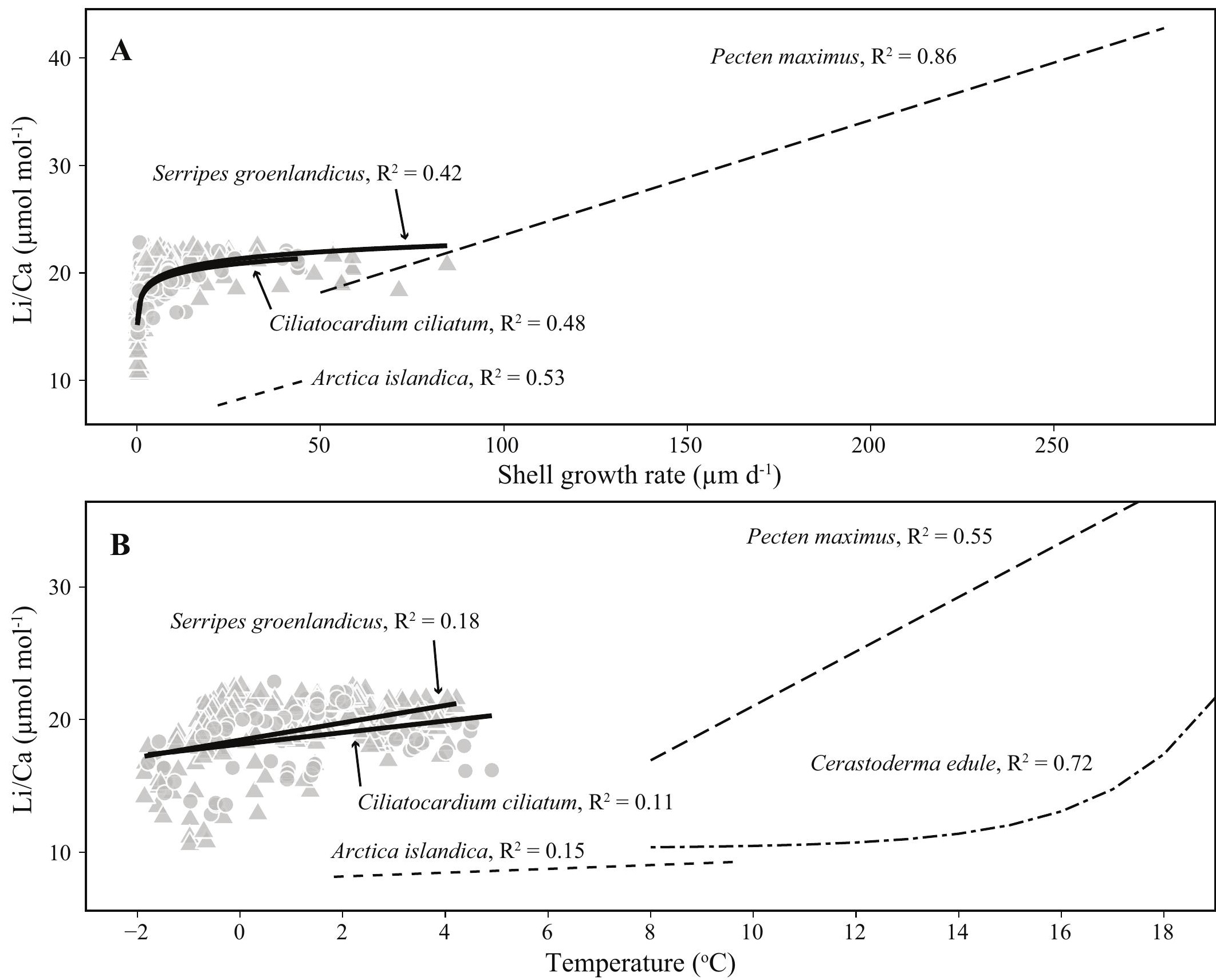




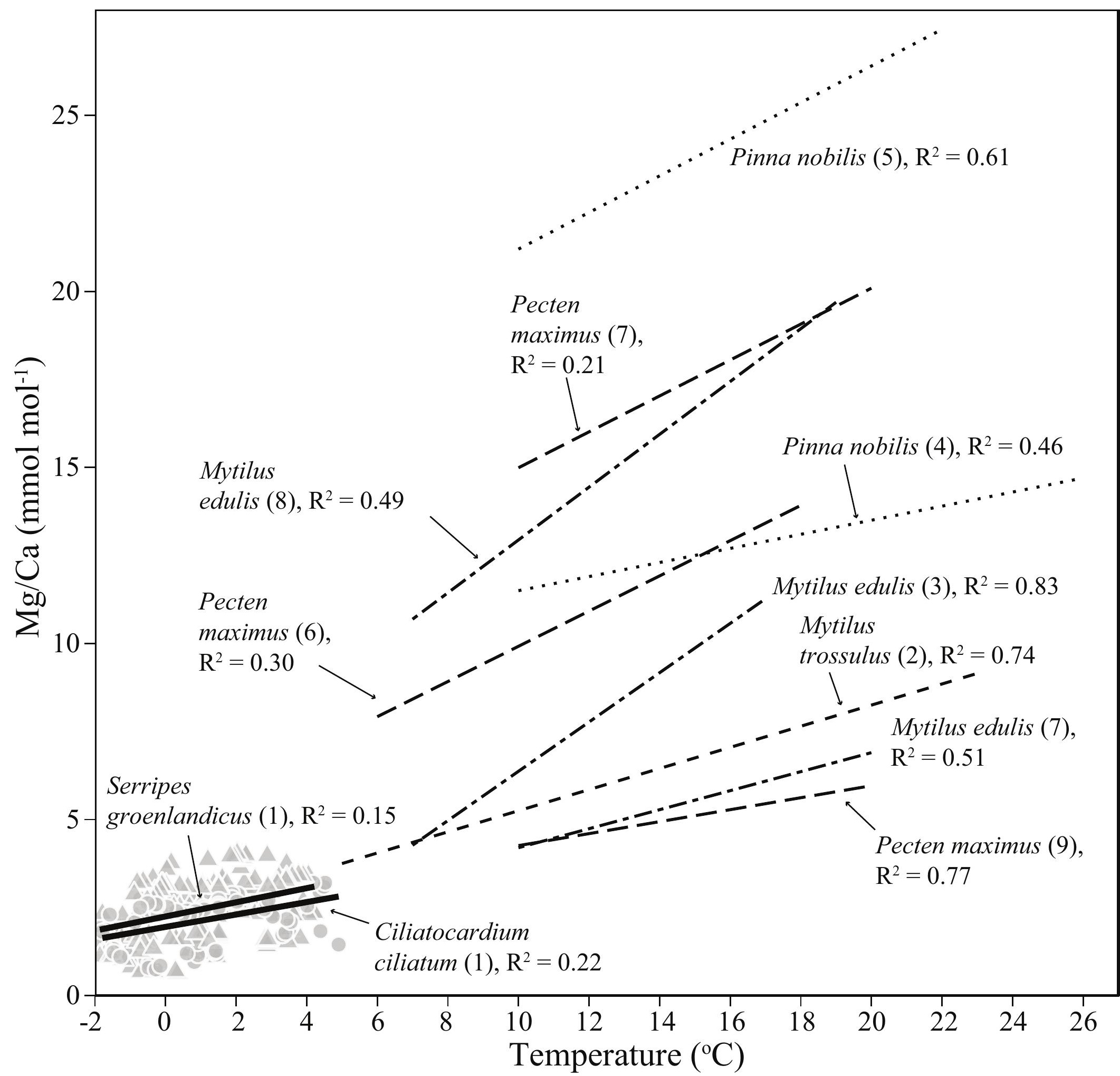




\section{Main article tables}

Table 1:

\begin{tabular}{llllcc}
\hline Year & Fjord & Depth $(\mathrm{m})$ & Basket & Serripes & Ciliatocardium \\
\hline $2007-2008$ & Kongsfjorden & 25 & KB & 2 & 2 \\
$2007-2008$ & Rijpfjorden & 25 & RB & 2 & 2 \\
$2009-2010$ & Kongsfjorden & 15 & RA & 2 & 3 \\
$2009-2010$ & Rijpfjorden & 15 & RA & $3(2)$ & $1(1)$ \\
$2009-2010$ & Kongsfjorden & 25 & RB & $4(2)$ & $1(1)$ \\
$2009-2010$ & Rijpfjorden & 25 & RB & $4(2)$ & $4(1)$ \\
\hline
\end{tabular}

Table 2:

\begin{tabular}{lllllcc}
\hline & & \multicolumn{2}{c}{$2007-2008$} & & \multicolumn{2}{c}{$2009-2010$} \\
\cline { 3 - 4 } \cline { 6 - 7 } Variable & Instrument & Kongsfjorden & Rijpfjorden & & Kongsfjorden & Rijpfjorden \\
\hline Temperature & TidBit & \multicolumn{3}{c}{$15 \& 25$} & & \multicolumn{3}{c}{$15 \& 25$} \\
Fluorescence & Fluorometer & 30 & 17 & & 36 & 10 \\
Salinity & CTD & 30 & 17 & & 36 & $10 \& 26$ \\
\hline
\end{tabular}


Table 3:

\begin{tabular}{|c|c|c|c|c|c|c|c|}
\hline \multirow[b]{2}{*}{ Ratio } & \multirow[b]{2}{*}{ Year } & \multirow[b]{2}{*}{ Basket } & \multirow[b]{2}{*}{$\mathrm{n}$} & \multicolumn{2}{|c|}{ Minimum } & \multicolumn{2}{|c|}{ Maximum } \\
\hline & & & & $\bar{x}$ & $\mathrm{CV}$ & $\bar{x}$ & $\mathrm{CV}$ \\
\hline \multirow{4}{*}{$\begin{array}{l}\mathrm{Li} / \mathrm{Ca} \\
(\mu \mathrm{mol} \\
\left.\mathrm{mol}^{-} 1\right)\end{array}$} & 2010 & $\mathrm{KA}$ & 5 & 13.6 & 14.1 & 22.5 & 4.4 \\
\hline & 2010 & $\mathrm{~KB}$ & 5 & 13.1 & 13.5 & 21.9 & 6.0 \\
\hline & 2010 & $\mathrm{RA}$ & 4 & 14.9 & 7.5 & 22.0 & 1.8 \\
\hline & 2010 & $\mathrm{RB}$ & 8 & 14.1 & 9.0 & 20.8 & 6.9 \\
\hline \multirow{4}{*}{$\begin{array}{l}\mathrm{Li} / \mathrm{Mg} \\
(\mathrm{mmol} \\
\left.\mathrm{mol}^{-1} 1\right)\end{array}$} & 2010 & $\mathrm{KA}$ & $J$ & 6.7 & 10.4 & 13.9 & 34.5 \\
\hline & 2010 & $\mathrm{~KB}$ & 5 & 6.2 & 13.7 & 18.2 & 13.8 \\
\hline & 2010 & RA & 4 & 6.7 & 20.2 & 13.3 & 8.6 \\
\hline & 2010 & $\mathrm{RB}$ & 8 & 6.9 & 25.3 & 12.9 & 21.0 \\
\hline \multirow{4}{*}{$\begin{array}{l}\mathrm{Li} / \mathrm{Sr} \\
(\mathrm{mmol} \\
\left.\mathrm{mol}^{-1}\right)\end{array}$} & 2010 & $\mathrm{KA}$ & 5 & 7.8 & 21.1 & 13.9 & 16.2 \\
\hline & 2010 & $\mathrm{~KB}$ & 5 & 7.9 & 10.9 & 15.1 & 3.1 \\
\hline & 2010 & $\mathrm{RA}$ & 4 & 6.6 & 12.8 & 14.7 & 20.8 \\
\hline & 2010 & $\mathrm{RB}$ & 8 & 7.2 & 16.8 & 14.6 & 6.8 \\
\hline \multirow{6}{*}{$\begin{array}{l}\mathrm{Mg} / \mathrm{Ca} \\
(\mathrm{mmol} \\
\left.\mathrm{mol}^{-1} 1\right)\end{array}$} & 2008 & $\mathrm{~KB}$ & 4 & 0.90 & 30.4 & 2.40 & 37.5 \\
\hline & 2008 & $\mathrm{RB}$ & 4 & 0.63 & 34.4 & 1.87 & 39.2 \\
\hline & 2010 & $\mathrm{KA}$ & 5 & 1.11 & 35.0 & 3.04 & 9.0 \\
\hline & 2010 & $\mathrm{~KB}$ & 5 & 0.87 & 31.3 & 3.13 & 6.3 \\
\hline & 2010 & RA & 4 & 1.28 & 6.7 & 3.14 & 21.6 \\
\hline & 2010 & $\mathrm{RB}$ & 8 & 1.22 & 25.1 & 2.90 & 29.1 \\
\hline \multirow{6}{*}{$\begin{array}{l}\mathrm{Mn} / \mathrm{Ca} \\
(\mu \mathrm{mol} \\
\left.\mathrm{mol}^{-1} 1\right)\end{array}$} & 2008 & $\mathrm{~KB}$ & 4 & 0.38 & 56.0 & 8.52 & 107.8 \\
\hline & 2008 & $\mathrm{RB}$ & 4 & 0.75 & 77.9 & 7.52 & 84.2 \\
\hline & 2010 & $\mathrm{KA}$ & 5 & 0.19 & 45.6 & 3.75 & 32.9 \\
\hline & 2010 & $\mathrm{~KB}$ & 5 & 0.16 & 41.8 & 1.31 & 51.8 \\
\hline & 2010 & RA & 4 & 0.17 & 25.0 & 1.89 & 48.8 \\
\hline & 2010 & $\mathrm{RB}$ & 8 & 0.20 & 65.8 & 1.68 & 51.2 \\
\hline \multirow{6}{*}{$\begin{array}{l}\mathrm{Sr} / \mathrm{Ca} \\
(\mathrm{mmol} \\
\left.\mathrm{mol}^{-} 1\right)\end{array}$} & 2008 & $\mathrm{~KB}$ & 4 & 1.23 & 8.8 & 2.53 & 21.9 \\
\hline & 2008 & $\mathrm{RB}$ & 4 & 1.36 & 22.1 & 2.63 & 35.4 \\
\hline & 2010 & KA & 5 & 1.35 & 13.7 & 2.32 & 17.5 \\
\hline & 2010 & $\mathrm{~KB}$ & 5 & 1.28 & 6.2 & 2.17 & 10.0 \\
\hline & 2010 & RA & 4 & 1.47 & 24.8 & 2.53 & 13.7 \\
\hline & 2010 & $\mathrm{RB}$ & 8 & 1.28 & 7.3 & 2.24 & 18.0 \\
\hline \multirow{6}{*}{$\begin{array}{l}\mathrm{Ba} / \mathrm{Ca} \\
(\mu \mathrm{mol} \\
\left.\mathrm{mol}^{-1} 1\right)\end{array}$} & 2008 & $\mathrm{~KB}$ & 4 & 0.61 & 10.8 & 49.1 & 23.6 \\
\hline & 2008 & $\mathrm{RB}$ & 4 & 0.74 & 25.5 & 25.2 & 139.9 \\
\hline & 2010 & KA & 5 & 0.69 & 18.2 & 11.2 & 48.2 \\
\hline & 2010 & $\mathrm{~KB}$ & 5 & 0.50 & 10.9 & 14.0 & 47.8 \\
\hline & 2010 & $\mathrm{RA}$ & 4 & 0.67 & 30.8 & 17.1 & 25.1 \\
\hline & 2010 & $\mathrm{RB}$ & 8 & 0.52 & 11.0 & 4.3 & 27.2 \\
\hline
\end{tabular}


Table 4:

\begin{tabular}{|c|c|c|c|c|c|c|c|c|c|}
\hline \multirow[b]{2}{*}{ Sample } & \multirow[b]{2}{*}{ Basket } & \multirow[b]{2}{*}{ Species } & \multirow[b]{2}{*}{$\begin{array}{c}\text { Mn max } \\
\left(\mu \mathrm{mol} \mathrm{mol}{ }^{-1}\right)\end{array}$} & \multicolumn{3}{|c|}{ Timing of $\mathrm{Mn} / \mathrm{Ca} \max$} & \multicolumn{3}{|c|}{ After fluorescence peak } \\
\hline & & & & $\begin{array}{l}\text { Centroid } \\
\text { (date) }\end{array}$ & $\begin{array}{c}\text { Min } \\
\text { (-days) }\end{array}$ & $\begin{array}{c}\text { Max } \\
(+ \text { days })\end{array}$ & $\begin{array}{l}\text { Centroid } \\
\text { (days) }\end{array}$ & $\begin{array}{l}\text { Min } \\
\text { (days) }\end{array}$ & $\begin{array}{c}\text { Max } \\
\text { (days) }\end{array}$ \\
\hline $\mathrm{A}$ & KB & Ser & 1.4 & $19 \mathrm{Jul}$ & 4 & 5 & 65 & 61 & 70 \\
\hline B & KB & Ser & 1.0 & 28 May & 12 & 55 & 13 & 1 & 68 \\
\hline $\mathrm{C}$ & KB & Cil & 0.6 & 1 Jun & 3 & 33 & 17 & 14 & 50 \\
\hline Average & $\mathrm{KB}$ & & 1.0 & 15 Jun & 6 & 31 & 32 & 25 & 63 \\
\hline $\mathrm{D}$ & RA & Ser & 2.9 & $5 \mathrm{Jul}$ & 1 & 8 & 12 & 11 & 20 \\
\hline $\mathrm{E}$ & $\mathrm{RA}$ & Ser & 1.2 & $5 \mathrm{Jul}$ & 2 & 5 & 12 & 10 & 17 \\
\hline $\mathrm{F}$ & $\mathrm{RA}$ & Cil & 0.9 & $22 \mathrm{Jul}$ & 0 & 1 & 29 & 29 & 30 \\
\hline Average & $\mathrm{RA}$ & & 1.7 & $10 \mathrm{Jul}$ & 1 & 5 & 18 & 17 & 22 \\
\hline $\mathrm{G}$ & $\mathrm{RB}$ & Ser & 2.4 & $29 \mathrm{Jul}$ & 1 & 0 & 36 & 35 & 36 \\
\hline $\mathrm{H}$ & $\mathrm{RB}$ & Ser & 2.6 & $28 \mathrm{Jul}$ & 0 & 1 & 35 & 35 & 36 \\
\hline I & $\mathrm{RB}$ & Cil & 0.8 & $27 \mathrm{Jul}$ & 3 & 1 & 34 & 31 & 35 \\
\hline Average & $\mathrm{RB}$ & & 1.9 & $28 \mathrm{Jul}$ & 1 & 1 & 35 & 34 & 36 \\
\hline
\end{tabular}

Table 5:

\begin{tabular}{|c|c|c|c|c|c|c|c|c|c|}
\hline \multirow[b]{2}{*}{ Sample } & \multirow[b]{2}{*}{ Basket } & \multirow[b]{2}{*}{ Species } & \multirow[b]{2}{*}{$\begin{array}{c}\mathrm{Ba} \max \\
\left(\mu \mathrm{mol} \mathrm{mol}{ }^{-1}\right)\end{array}$} & \multicolumn{3}{|c|}{ Timing of $\mathrm{Ba} / \mathrm{Ca} \max$} & \multicolumn{3}{|c|}{ After fluorescence peak } \\
\hline & & & & $\begin{array}{c}\text { Centroid } \\
\text { (date) }\end{array}$ & $\begin{array}{c}\text { Min } \\
\text { (-days) }\end{array}$ & $\begin{array}{c}\text { Max } \\
(+ \text { days })\end{array}$ & $\begin{array}{c}\text { Centroid } \\
\text { (days) }\end{array}$ & $\begin{array}{c}\text { Min } \\
\text { (days) }\end{array}$ & $\begin{array}{c}\text { Max } \\
\text { (days) }\end{array}$ \\
\hline $\mathrm{A}$ & $\mathrm{KB}$ & Ser & 9.9 & 4 Aug & 11 & 1 & 81 & 70 & 82 \\
\hline $\mathrm{B}$ & $\mathrm{KB}$ & Ser & 8.2 & $22 \mathrm{Jul}$ & 50 & 32 & 68 & 18 & 100 \\
\hline $\mathrm{C}$ & $\mathrm{KB}$ & Cil & 23.4 & $27 \mathrm{Jul}$ & 30 & 11 & 73 & 43 & 84 \\
\hline Average & $\mathrm{KB}$ & & 13.8 & $28 \mathrm{Jul}$ & 30 & 15 & 74 & 44 & 89 \\
\hline $\mathrm{D}$ & RA & Ser & 21.9 & $5 \mathrm{Jul}$ & 1 & 10 & 12 & 11 & 22 \\
\hline $\mathrm{E}$ & RA & Ser & 12.4 & $8 \mathrm{Jul}$ & 4 & 3 & 15 & 11 & 18 \\
\hline $\mathrm{F}$ & RA & Cil & 14.9 & $23 \mathrm{Jul}$ & 1 & 3 & 30 & 29 & 33 \\
\hline Average & $\mathrm{RA}$ & & 16.4 & $12 \mathrm{Jul}$ & 2 & 5 & 19 & 17 & 24 \\
\hline $\mathrm{G}$ & $\mathrm{RB}$ & Ser & 5.2 & $17 \mathrm{Jul}$ & 1 & 1 & 24 & 23 & 25 \\
\hline $\mathrm{H}$ & $\mathrm{RB}$ & Ser & 3.1 & 29 Jul & 1 & 0 & 36 & 35 & 36 \\
\hline I & $\mathrm{RB}$ & Cil & 5.7 & $28 \mathrm{Jul}$ & 0 & 0 & 35 & 35 & 35 \\
\hline Average & $\mathrm{RB}$ & & 4.7 & $24 \mathrm{Jul}$ & 1 & 0 & 32 & 31 & 32 \\
\hline
\end{tabular}




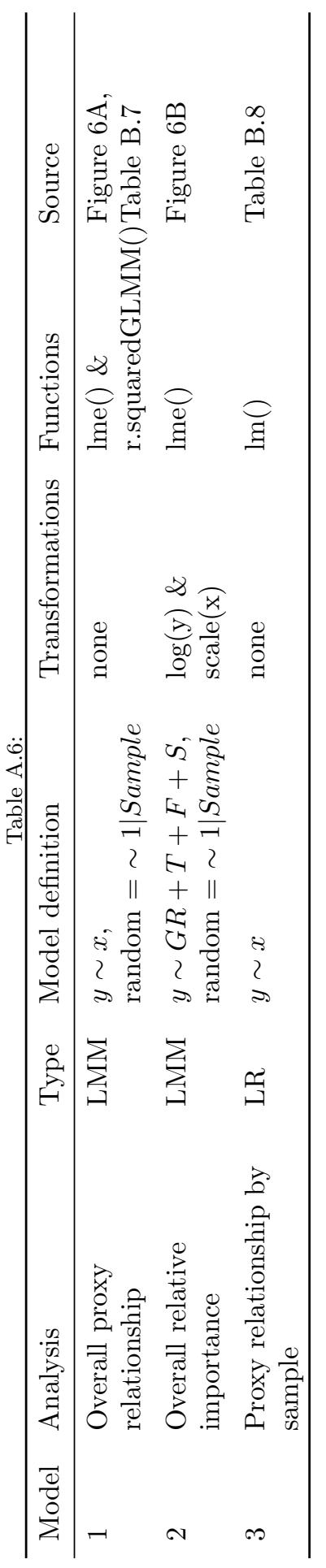




\section{Appendix B. tables}

Table B.7:

\begin{tabular}{|c|c|c|c|c|c|c|c|c|c|}
\hline \multirow[b]{2}{*}{ Ratio } & \multirow[b]{2}{*}{ Fixef } & \multirow[b]{2}{*}{ Par } & \multicolumn{3}{|c|}{ Fixed effects } & \multicolumn{2}{|c|}{$\mathrm{R}^{2}$} & \multicolumn{2}{|c|}{ Standard error } \\
\hline & & & Min & Est & $\operatorname{Max}$ & Marg & Cond & Rand & Res \\
\hline \multirow[t]{8}{*}{$\mathrm{Li} / \mathrm{Ca}$} & GR & Int & 14.92 & 15.62 & 16.33 & 0.43 & 0.51 & 0.69 & 1.76 \\
\hline & & $\mathrm{Sl}$ & 0.90 & 1.06 & 1.21 & & & & \\
\hline & $\mathrm{T}$ & Int & 17.57 & 18.30 & 19.03 & 0.15 & 0.31 & 1.00 & 2.08 \\
\hline & & $\mathrm{Sl}$ & 0.42 & 0.57 & 0.72 & & & & \\
\hline & $\mathrm{F}$ & Int & 17.96 & 18.84 & 19.71 & $<0.01$ & 0.18 & 1.07 & 2.29 \\
\hline & & $\mathrm{Sl}$ & -1.25 & 0.78 & 2.82 & & & & \\
\hline & S & Int & 25.98 & 42.92 & 59.85 & 0.03 & 0.17 & 0.91 & 2.27 \\
\hline & & $\mathrm{Sl}$ & -1.22 & -0.71 & -0.21 & & & & \\
\hline \multirow[t]{8}{*}{$\mathrm{Li} / \mathrm{Mg}$} & GR & Int & 10.76 & 11.97 & 13.18 & 0.2 & 0.42 & 1.46 & 2.38 \\
\hline & & $\mathrm{Sl}$ & -1.12 & -0.91 & -0.70 & & & & \\
\hline & $\mathrm{T}$ & Int & 8.74 & 9.81 & 10.89 & 0.11 & 0.35 & 1.54 & 2.50 \\
\hline & & $\mathrm{Sl}$ & -0.78 & -0.60 & -0.42 & & & & \\
\hline & $\mathrm{F}$ & Int & 9.04 & 10.17 & 11.30 & 0.06 & 0.29 & 1.47 & 2.61 \\
\hline & & $\mathrm{Sl}$ & -7.48 & -5.15 & -2.82 & & & & \\
\hline & S & Int & -34.99 & -14.74 & 5.50 & 0.02 & 0.25 & 1.46 & 2.67 \\
\hline & & $\mathrm{Sl}$ & 0.11 & 0.71 & 1.31 & & & & \\
\hline \multirow[t]{8}{*}{$\mathrm{Li} / \mathrm{Sr}$} & GR & int & 7.98 & 8.99 & 10.01 & 0.25 & 0.42 & 1.17 & 2.15 \\
\hline & & $\mathrm{sl}$ & 0.71 & 0.90 & 1.09 & & & & \\
\hline & $\mathrm{T}$ & int & 11.35 & 11.98 & 12.61 & 0 & 0.09 & 0.76 & 2.50 \\
\hline & & sl & -0.29 & -0.11 & 0.07 & & & & \\
\hline & $\mathrm{F}$ & int & 12.23 & 13.07 & 13.90 & 0.1 & 0.23 & 0.97 & 2.37 \\
\hline & & $\mathrm{sl}$ & -7.80 & -5.70 & -3.60 & & & & \\
\hline & S & int & -29.91 & -11.67 & 6.56 & 0.03 & 0.11 & 0.77 & 2.48 \\
\hline & & $\mathrm{sl}$ & 0.16 & 0.70 & 1.24 & & & & \\
\hline \multirow[t]{8}{*}{$\mathrm{Mg} / \mathrm{Ca}$} & GR & Int & 1.05 & 1.39 & 1.73 & 0.3 & 0.57 & 0.45 & 0.56 \\
\hline & & $\mathrm{Sl}$ & 0.25 & 0.30 & 0.35 & & & & \\
\hline & $\mathrm{T}$ & Int & 1.76 & 2.09 & 2.42 & 0.17 & 0.49 & 0.48 & 0.61 \\
\hline & & $\mathrm{Sl}$ & 0.16 & 0.21 & 0.25 & & & & \\
\hline & $\mathrm{F}$ & Int & 1.85 & 2.19 & 2.54 & 0.02 & 0.32 & 0.46 & 0.69 \\
\hline & & $\mathrm{Sl}$ & 0.09 & 0.71 & 1.33 & & & & \\
\hline & S & Int & 7.37 & 12.56 & 17.76 & 0.05 & 0.35 & 0.46 & 0.68 \\
\hline & & $\mathrm{Sl}$ & -0.46 & -0.30 & -0.15 & & & & \\
\hline \multirow[t]{6}{*}{$\mathrm{Mn} / \mathrm{Ca}$} & GR & Int & -0.07 & 0.16 & 0.39 & 0.22 & 0.51 & 0.30 & 0.39 \\
\hline & & $\mathrm{Sl}$ & 0.13 & 0.17 & 0.20 & & & & \\
\hline & $\mathrm{T}$ & Int & 0.46 & 0.71 & 0.96 & $<0.01$ & 0.39 & 0.37 & 0.46 \\
\hline & & $\mathrm{Sl}$ & -0.04 & 0.00 & 0.03 & & & & \\
\hline & $\mathrm{F}$ & Int & 0.53 & 0.79 & 1.04 & 0.01 & 0.39 & 0.36 & 0.45 \\
\hline & & $\mathrm{Sl}$ & -0.81 & -0.41 & 0.00 & & & & \\
\hline
\end{tabular}


Table B.7: (continued)

\begin{tabular}{|c|c|c|c|c|c|c|c|c|c|}
\hline \multirow[b]{2}{*}{ Ratio } & \multirow[b]{2}{*}{ Fixef } & \multirow[b]{2}{*}{ Par } & \multicolumn{3}{|c|}{ Fixed effects } & \multicolumn{2}{|c|}{$\mathrm{R}^{2}$} & \multicolumn{2}{|c|}{ Standard error } \\
\hline & & & Min & Est & $\operatorname{Max}$ & Marg & Cond & Rand & Res \\
\hline & S & Int & -4.89 & -1.41 & 2.06 & $<0.01$ & 0.41 & 0.38 & 0.45 \\
\hline & & $\mathrm{Sl}$ & -0.04 & 0.06 & 0.17 & & & & \\
\hline \multirow[t]{8}{*}{$\mathrm{Sr} / \mathrm{Ca}$} & GR & Int & 1.70 & 1.86 & 2.02 & 0.07 & 0.38 & 0.20 & 0.29 \\
\hline & & $\mathrm{Sl}$ & -0.09 & -0.06 & -0.04 & & & & \\
\hline & $\mathrm{T}$ & Int & 1.46 & 1.58 & 1.70 & 0.09 & 0.33 & 0.17 & 0.28 \\
\hline & & $\mathrm{Sl}$ & 0.04 & 0.06 & 0.08 & & & & \\
\hline & $\mathrm{F}$ & Int & 1.28 & 1.43 & 1.58 & 0.18 & 0.5 & 0.21 & 0.26 \\
\hline & & $\mathrm{Sl}$ & 0.83 & 1.07 & 1.30 & & & & \\
\hline & S & Int & 6.01 & 8.16 & 10.31 & 0.13 & 0.3 & 0.14 & 0.28 \\
\hline & & $\mathrm{Sl}$ & -0.26 & -0.19 & -0.13 & & & & \\
\hline \multirow[t]{8}{*}{$\mathrm{Mo} / \mathrm{Ca}$} & GR & Int & 48.7 & 61.9 & 75.0 & 0.08 & 0.61 & 18.6 & 15.9 \\
\hline & & $\mathrm{Sl}$ & -5.9 & -4.5 & -3.1 & & & & \\
\hline & $\mathrm{T}$ & Int & 34.5 & 47.2 & 59.8 & $<0.01$ & 0.55 & 18.8 & 17.0 \\
\hline & & $\mathrm{Sl}$ & -1.0 & 0.3 & 1.5 & & & & \\
\hline & $\mathrm{F}$ & Int & 31.5 & 44.2 & 57.0 & 0.01 & 0.55 & 18.5 & 16.9 \\
\hline & & $\mathrm{Sl}$ & -0.1 & 15.2 & 30.4 & & & & \\
\hline & $\mathrm{S}$ & Int & 68.2 & 198.2 & 328.2 & 0.01 & 0.56 & 19.0 & 16.9 \\
\hline & & $\mathrm{Sl}$ & -8.3 & -4.5 & -0.6 & & & & \\
\hline \multirow[t]{8}{*}{$\mathrm{Ba} / \mathrm{Ca}$} & GR & Int & 0.01 & 1.16 & 2.32 & 0.02 & 0.08 & 0.86 & 3.38 \\
\hline & & $\mathrm{Sl}$ & 0.05 & 0.34 & 0.62 & & & & \\
\hline & $\mathrm{T}$ & Int & 1.89 & 2.59 & 3.29 & 0.02 & 0.06 & 0.73 & 3.39 \\
\hline & & $\mathrm{Sl}$ & -0.53 & -0.29 & -0.04 & & & & \\
\hline & $\mathrm{F}$ & Int & 1.78 & 2.68 & 3.59 & 0.01 & 0.06 & 0.77 & 3.41 \\
\hline & & $\mathrm{Sl}$ & -5.05 & -2.09 & 0.86 & & & & \\
\hline & $\mathrm{S}$ & Int & -36.36 & -11.72 & 12.92 & 0.01 & 0.06 & 0.80 & 3.41 \\
\hline & & $\mathrm{Sl}$ & -0.32 & 0.42 & 1.15 & & & & \\
\hline
\end{tabular}




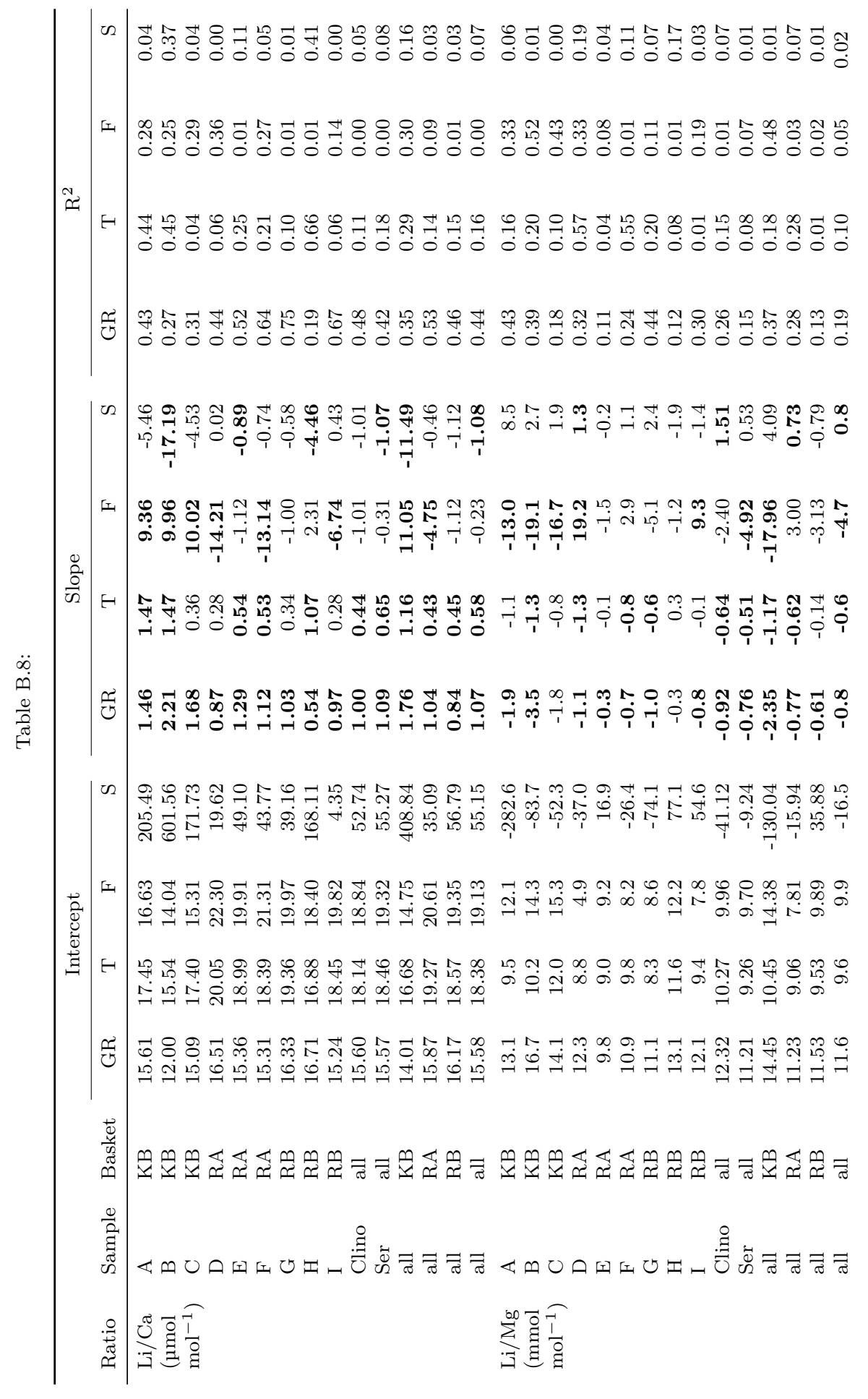




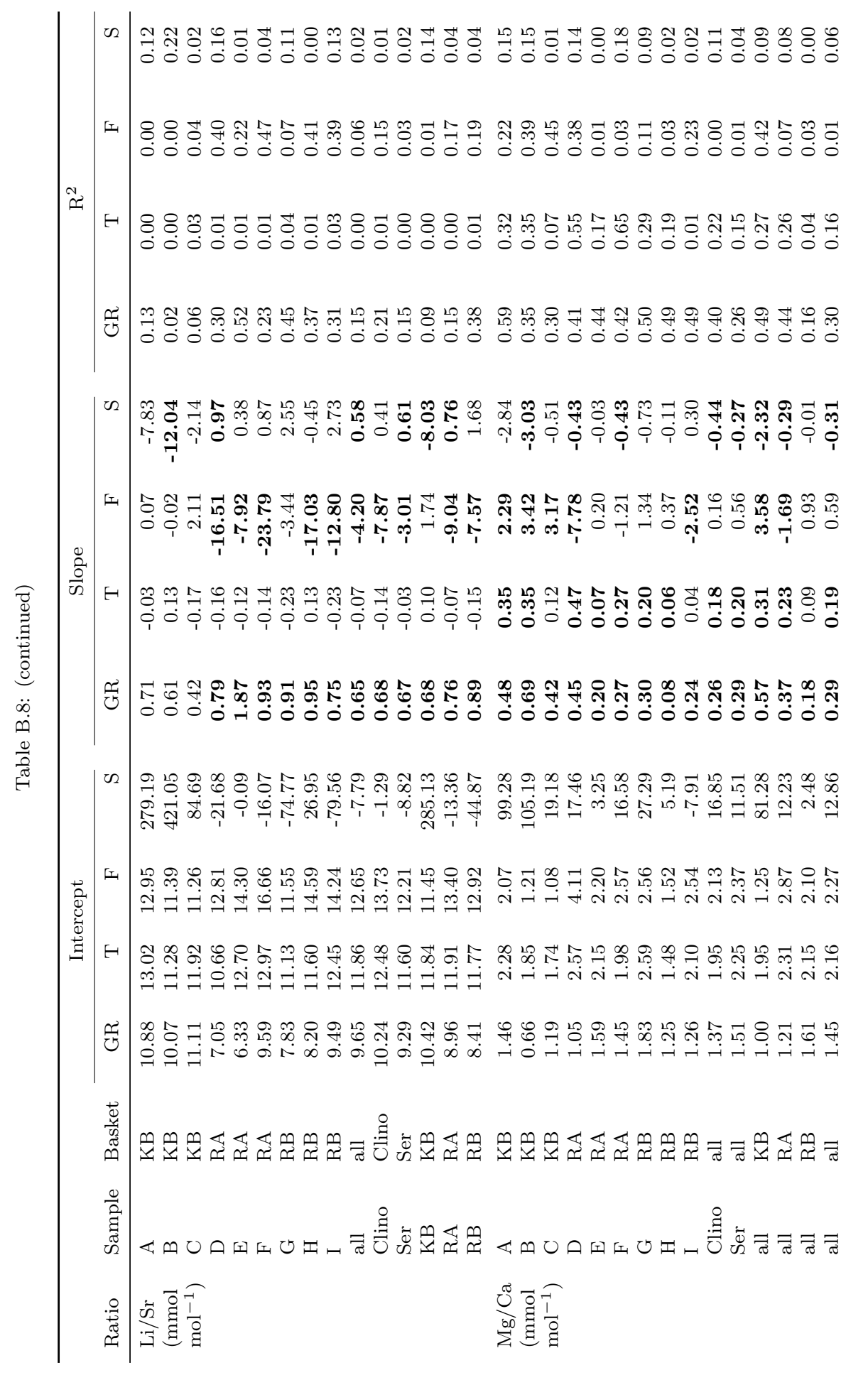




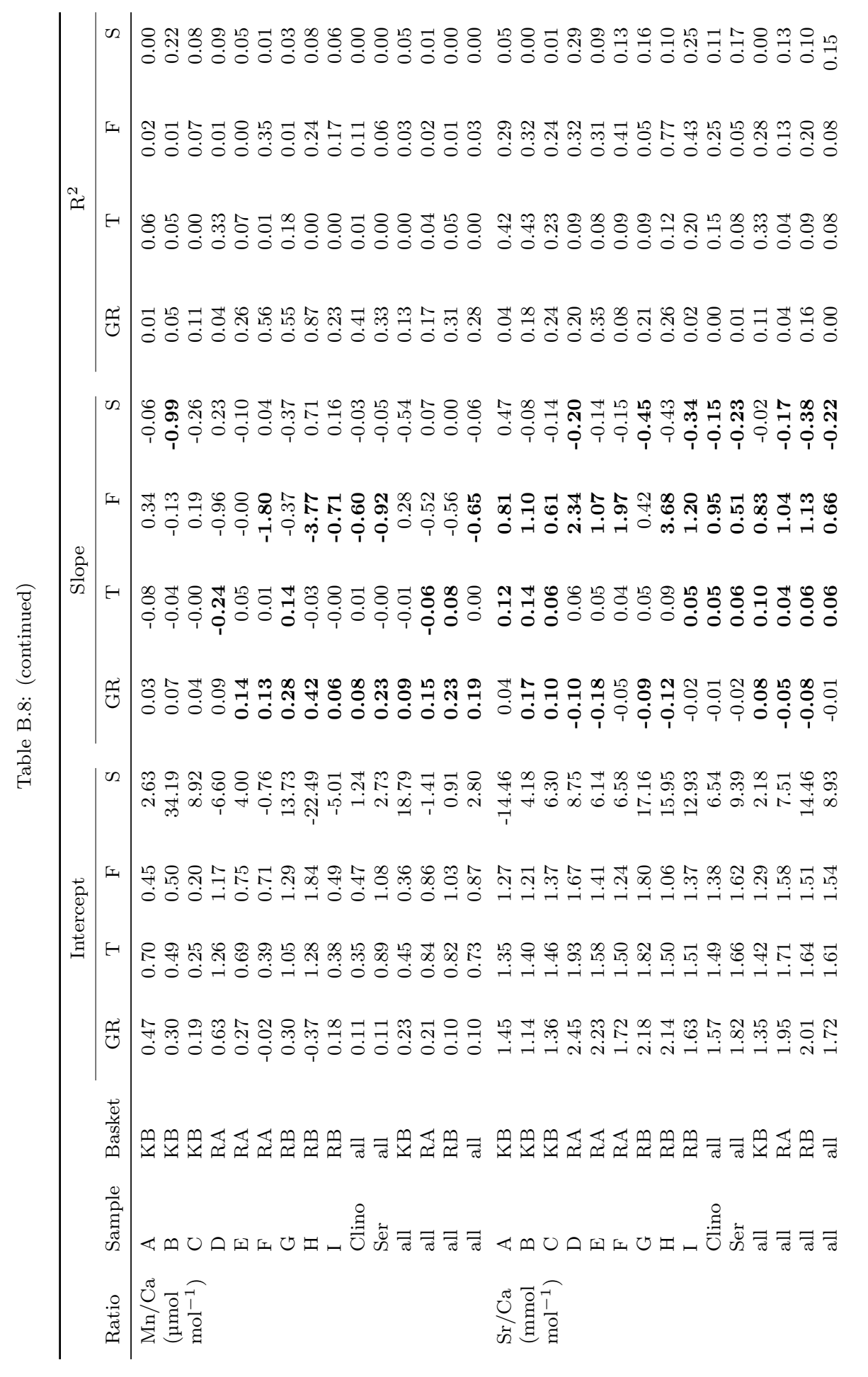




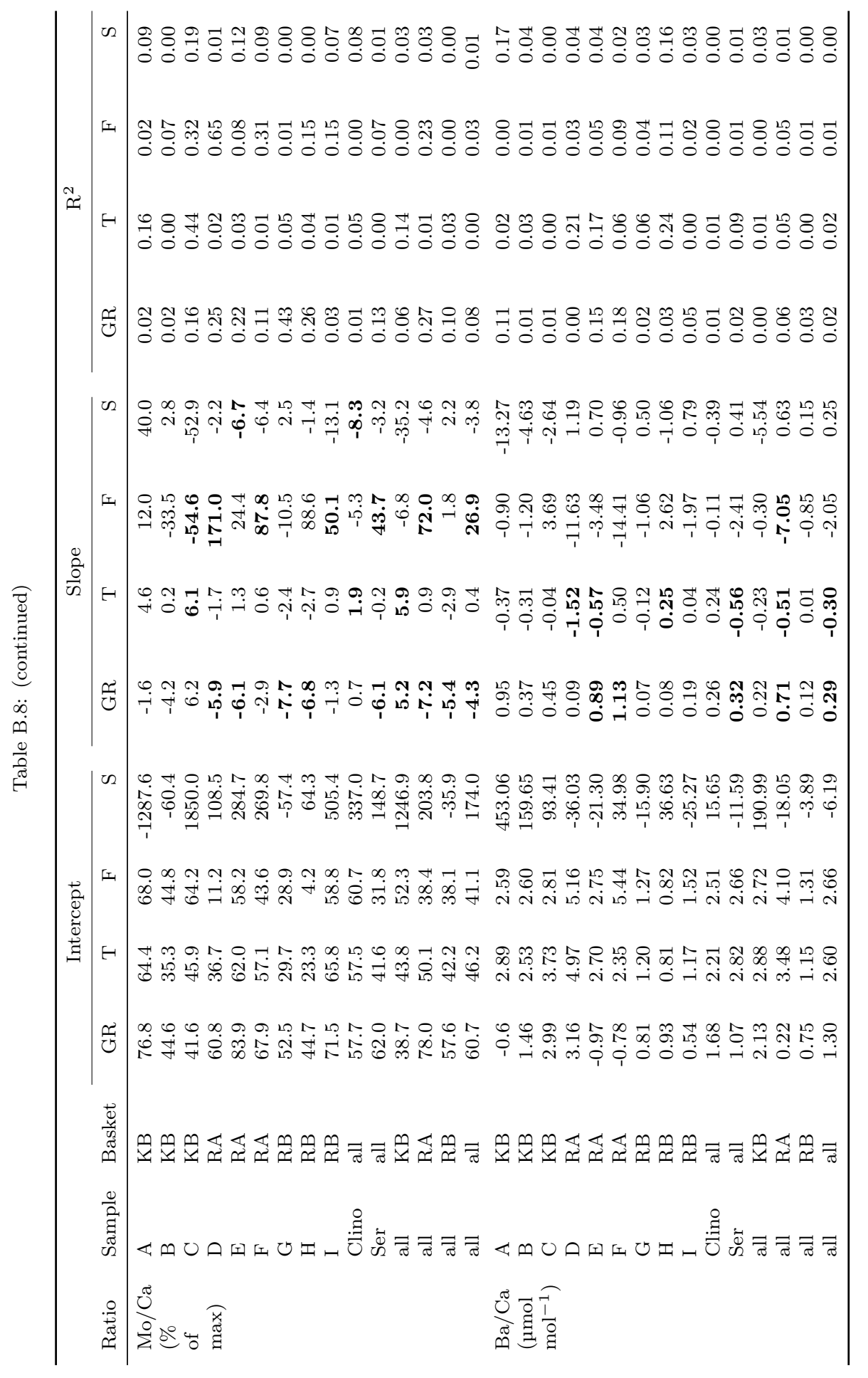




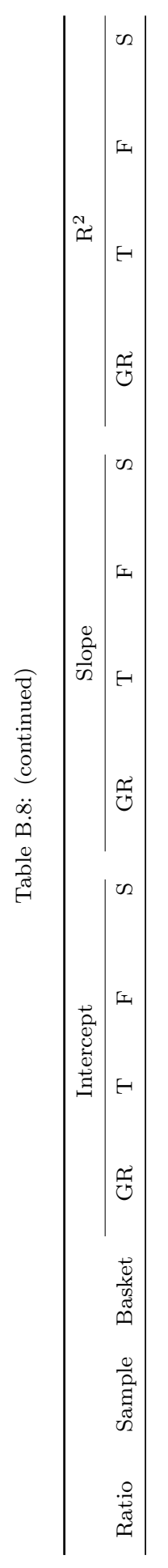


Table B.9:

\begin{tabular}{|c|c|c|c|c|c|}
\hline Pair & Group & $\mathrm{n}$ & $\mathrm{r}_{z}$ & $\mathrm{r}_{\min }$ & $\mathrm{r}_{\max }$ \\
\hline $\mathrm{Mg}-\mathrm{Mn}$ & $(2007-2008)$ & 8 & 0.38 & -0.31 & 0.78 \\
\hline$-\mathrm{Ba}$ & 008) & 6 & 0.24 & -0.32 & 0.61 \\
\hline & $(2007-2008)$ & 8 & 0.13 & & 0.73 \\
\hline & (2007-2008) & 8 & 0.06 & -0.57 & 0.76 \\
\hline & & 6 & 0.00 & & 0.37 \\
\hline $\mathrm{Mr}-\mathrm{Sr}$ & $\left(\sigma, c^{\circ}\right.$ & 6 & -0.17 & -0.36 & 0.16 \\
\hline & $J$ & 22 & & & 0.92 \\
\hline & ) & 2 & 0.68 & & 0.91 \\
\hline -Mo & Copor & 2 & 0.59 & & \\
\hline$-M n$ & (rage & 2 & 0.50 & & 0.82 \\
\hline g-LiSr & (1) & 2 & 0.47 & & 0.90 \\
\hline & ) & 2 & 0.38 & & 0.87 \\
\hline & ) & 22 & 0.35 & & 0.85 \\
\hline & ) & 22 & 0.32 & & 0.85 \\
\hline & ) & 22 & 0.30 & & 0.78 \\
\hline $\mathrm{LiSr}$ & ) & 22 & 0.25 & & 0.70 \\
\hline & ) & 22 & 0.17 & & 0.65 \\
\hline & ) & 22 & 0.11 & & 0.59 \\
\hline$I_{0}$ & ) & 22 & 0.01 & & 0.67 \\
\hline $\mathrm{g}-\mathrm{Sr}$ & ) & 22 & 0.00 & & 0.79 \\
\hline Ba-LiMg & ) & 22 & -0.08 & & 0.57 \\
\hline $\mathrm{r}$ & ) & 22 & -0.11 & -0 & 0.95 \\
\hline & ) & 22 & -0.12 & -0 & 0.86 \\
\hline 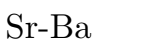 & ) & 22 & -0.15 & -0 & 0.51 \\
\hline & 0) & 22 & -0.21 & -0 & 0.38 \\
\hline M & 0) & 22 & -0.25 & -0 & 0.57 \\
\hline & & 22 & -0.26 & -0 & 0.62 \\
\hline $\mathrm{L}$ & & 22 & -0.31 & -0 & 0.48 \\
\hline & 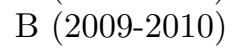 & 22 & -0.32 & -0.77 & 0.44 \\
\hline$M_{0}$ & & 22 & -0.42 & -0.89 & 0.61 \\
\hline 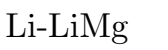 & & 22 & -0.52 & -0.87 & 0.32 \\
\hline $\mathrm{T} \cdot \mathrm{C}$ & ') & 22 & -0.66 & -0.96 & 0.12 \\
\hline & & 22 & -0.85 & -0.96 & -0.06 \\
\hline Mg-LiM & B $(2$ & 22 & -0.92 & -0.99 & -0.60 \\
\hline & & & & & \\
\hline & & 9 & 0.73 & 0.59 & 0.83 \\
\hline & & 9 & 0.64 & -0.12 & 0.90 \\
\hline & & 9 & 0.60 & 0.18 & 0.93 \\
\hline Sr-Mn & $a^{\prime}$ & 9 & 0.55 & 0.34 & 0.77 \\
\hline & $\mathrm{C}(\mathrm{r}$ & 9 & 0.54 & 0.03 & 0.81 \\
\hline LiMg-Mo & $\mathrm{C}$ (response) & 9 & 0.50 & -0.32 & 0.80 \\
\hline
\end{tabular}


Table B.9 (continued)

\begin{tabular}{llrrrr}
\hline Pair & Group & $\mathrm{n}$ & $\mathrm{r}_{z}$ & $\mathrm{r}_{\min }$ & $\mathrm{r}_{\max }$ \\
\hline Mn-Ba & C (response) & 9 & 0.50 & -0.02 & 0.78 \\
Mg-Mn & C (response) & 9 & 0.42 & -0.31 & 0.68 \\
LiSr-Ba & C (response) & 9 & 0.35 & 0.05 & 0.70 \\
Li-Ba & C (response) & 9 & 0.31 & -0.02 & 0.66 \\
Mg-Ba & C (response) & 9 & 0.25 & -0.23 & 0.59 \\
LiMg-Sr & C (response) & 9 & 0.04 & -0.77 & 0.71 \\
Mg-Sr & C (response) & 9 & -0.10 & -0.69 & 0.79 \\
Sr-Ba & C (response) & 9 & -0.16 & -0.47 & 0.33 \\
LiMg-Ba & C (response) & 9 & -0.18 & -0.46 & 0.18 \\
Li-Sr & C (response) & 9 & -0.23 & -0.60 & 0.58 \\
Mo-Ba & C (response) & 9 & -0.23 & -0.60 & 0.10 \\
LiMg-Mn & C (response) & 9 & -0.29 & -0.63 & 0.32 \\
Mn-Mo & C (response) & 9 & -0.33 & -0.57 & 0.04 \\
Sr-Mn & C (response) & 9 & -0.35 & -0.52 & 0.06 \\
LiMg-LiSr & C (response) & 9 & -0.42 & -0.87 & 0.35 \\
Li-Mo & C (response) & 9 & -0.46 & -0.67 & -0.07 \\
Mg-Mo & C (response) & 9 & -0.51 & -0.79 & -0.16 \\
Li-LiMg & C (response) & 9 & -0.60 & -0.78 & 0.40 \\
LiSr-Mo & C (response) & 9 & -0.66 & -0.84 & 0.07 \\
LiSr-Sr & C (response) & 9 & -0.84 & -0.93 & -0.23 \\
LiMg-Mg & C (response) & 9 & -0.92 & -0.97 & -0.60 \\
T-F & D (predictor) & 3 & 0.48 & 0.34 & 0.67 \\
GR-T & D (predictor) & 3 & 0.43 & 0.22 & 0.66 \\
GR-F & D (predictor) & 3 & 0.02 & -0.31 & 0.55 \\
GR-S & D (predictor) & 3 & -0.24 & -0.46 & -0.02 \\
S-F & D (predictor) & 3 & -0.28 & -0.64 & 0.08 \\
S-T & D (predictor) & 3 & -0.71 & -0.86 & -0.57 \\
\hline & & & & &
\end{tabular}

